\title{
Effect of freshwater mussels on the vertical distribution of anaerobic ammonia oxidizers and other nitrogen-transforming microorganisms in upper Mississippi river sediment
}

\author{
Ellen M Black $^{1}{ }^{\text {, }}$ Michael S Chimenti $^{2}{ }^{\text {, Craig L Just }}{ }^{\text {Corresp. } 1}$ \\ ${ }^{1}$ Department of Civil and Environmental Engineering, University of lowa, lowa City, lowa, United States \\ 2 Iowa Institute of Human Genetics, University of lowa, lowa City, lowa, United States \\ Corresponding Author: Craig L Just \\ Email address: craig-just@uiowa.edu
}

Targeted qPCR and non-targeted amplicon sequencing of 16S rRNA genes within sediment layers identified the anaerobic ammonium oxidation (anammox) niche and characterized microbial community changes attributable to freshwater mussels. Anammox bacteria were normally distributed (Shapiro-Wilk normality test, $W$-statistic $=0.954, p=0.773$ ) between 1$15 \mathrm{~cm}$ depth and were increased by a factor of $2.2(p<0.001)$ at $3 \mathrm{~cm}$ below the watersediment interface when mussels were present. Amplicon sequencing of sediment at depths relevant to mussel burrowing $(3$ and $5 \mathrm{~cm}$ ) showed that mussel presence reduced observed species richness $(p=0.005)$, Chaol diversity $(p=0.005)$, and Shannon diversity $(p<0.001)$, with more pronounced decreases at $5 \mathrm{~cm}$ depth. A non-metric,

multidimensional scaling model showed that intersample microbial species diversity varied as a function of mussel presence, indicating that sediment below mussels harbored distinct microbial communities. Mussel presence corresponded with a 4-fold decrease in a majority of operational taxonomic units (OTUs) classified in the phyla Gemmatimonadetes, Actinobacteria, Acidobacteria, Plantomycetes, Chloroflexi, Firmicutes, Crenarcheota, and Verrucomicrobia. 38 OTUs in the phylum Nitrospirae were differentially abundant $(p<0.001)$ with mussels, resulting in an overall increase from $25 \%$ to $35 \%$. Nitrogen (N)cycle OTUs significantly impacted by mussels belonged to anammmox genus Candidatus Brocadia, ammonium oxidizing bacteria family Nitrosomonadaceae, ammonium oxidizing archaea genus Candidatus Nitrososphaera, nitrite oxidizing bacteria in genus Nitrospira, and nitrate- and nitrite-dependent anaerobic methane oxidizing organisms in the archaeal family "ANME-2d" and bacterial phylum "NC10", respectively. Nitrosomonadaceae (0.9fold $(p<0.001))$ increased with mussels, while NC10 $(2.1$-fold $(p<0.001))$, ANME- $2 d(1.8$ fold $(p<0.001))$, and Candidatus Nitrososphaera $(1.5$-fold $(p<0.001))$ decreased with mussels. Co-occurrence of 2-fold increases in Candidatus Brocadia and Nitrospira in shallow sediments suggests that mussels may enhance microbial niches at the interface of 
oxic-anoxic conditions, presumably through biodeposition and burrowing. Furthermore, it is likely that the niches of Candidatus Nitrososphaera and n-damo were suppressed by mussel biodeposition and sediment aeration, as these phylotypes require low ammonium concentrations and anoxic conditions, respectively. As far as we know, this is the first study to characterize freshwater mussel impacts on microbial diversity and the vertical distribution of $\mathrm{N}$-cycle microorganisms in upper Mississippi river sediment. These findings advance our understanding of ecosystem services provided by mussels and their impact on aquatic biogeochemical N-cycling. 
1 Effect of freshwater mussels on the vertical distribution of anaerobic ammonia oxidizers 2 and other nitrogen-transforming microorganisms in upper Mississippi river sediment

3 Ellen M. Black ${ }^{1}$, Michael S. Chimenti ${ }^{2}$, Craig L. Just ${ }^{1}$

$4{ }^{1}$ Department of Civil and Environmental Engineering, University of Iowa, Iowa City, Iowa, 5 USA

$6 \quad 2$ Iowa Institute of Human Genetics, University of Iowa, Iowa City, Iowa, USA

8 Corresponding Author:

9 Craig Just

104111 Seamans Center, Iowa City, Iowa, 52242, USA

11 Email address: craig-just@uiowa.edu 


\section{Abstract}

13 Targeted qPCR and non-targeted amplicon sequencing of 16S rRNA genes within sediment layers identified the anaerobic ammonium oxidation (anammox) niche and characterized microbial community changes attributable to freshwater mussels. Anammox bacteria were normally distributed (Shapiro-Wilk normality test, $\mathrm{W}$-statistic $=0.954, \mathrm{p}=0.773$ ) between $1-15 \mathrm{~cm}$ depth and were increased by a factor of $2.2(\mathrm{p}<0.001)$ at $3 \mathrm{~cm}$ below the water-sediment interface when mussels were present. Amplicon sequencing of sediment at depths relevant to mussel burrowing ( 3 and $5 \mathrm{~cm}$ ) showed that mussel presence reduced observed species richness $(p=0.005)$, Chaol diversity $(p=0.005)$, and Shannon diversity $(p<0.001)$, with more pronounced decreases at $5 \mathrm{~cm}$ depth. A non-metric, multidimensional scaling model showed that intersample microbial species diversity varied as a function of mussel presence, indicating that sediment below mussels harbored distinct microbial communities. Mussel presence corresponded with a 4fold decrease in a majority of operational taxonomic units (OTUs) classified in the phyla Gemmatimonadetes, Actinobacteria, Acidobacteria, Plantomycetes, Chloroflexi, Firmicutes, Crenarcheota, and Verrucomicrobia. 38 OTUs in the phylum Nitrospirae were differentially abundant $(\mathrm{p}<0.001)$ with mussels, resulting in an overall increase from $25 \%$ to $35 \%$. genus Candidatus Brocadia, ammonium oxidizing bacteria family Nitrosomonadaceae, ammonium oxidizing archaea genus Candidatus Nitrososphaera, nitrite oxidizing bacteria in genus Nitrospira, and nitrate- and nitrite-dependent anaerobic methane oxidizing organisms in the archaeal family "ANME-2d" and bacterial phylum "NC10", respectively. Nitrosomonadaceae $(0.9$-fold $(\mathrm{p}<0.001))$ increased with mussels, while NC10 (2.1-fold $(\mathrm{p}<0.001))$, ANME-2d (1.8-fold $(\mathrm{p}<0.001))$, and Candidatus Nitrososphaera $(1.5$-fold $(\mathrm{p}<0.001))$ decreased with mussels. Co-occurrence of 2-fold increases in Candidatus Brocadia and 
36 Nitrospira in shallow sediments suggests that mussels may enhance microbial niches at the

37 interface of oxic-anoxic conditions, presumably through biodeposition and burrowing.

38 Furthermore, it is likely that the niches of Candidatus Nitrososphaera and n-damo were

39 suppressed by mussel biodeposition and sediment aeration, as these phylotypes require low

40 ammonium concentrations and anoxic conditions, respectively. As far as we know, this is the

41 first study to characterize freshwater mussel impacts on microbial diversity and the vertical

42 distribution of $\mathrm{N}$-cycle microorganisms in upper Mississippi river sediment. These findings

43 advance our understanding of ecosystem services provided by mussels and their impact on

44 aquatic biogeochemical N-cycling. 


\section{Introduction}

Native freshwater mussels (Order Unionida) are ecosystem engineers that significantly alter benthic habitats through biodeposition of feces and pseudofeces, rich in ammonium $\left(\mathrm{NH}_{4}{ }^{+}\right)$and organic carbon (C), into sediment (Thorp 1998, Vaughn 2004 and 2008, Bril, 2014). The estimated mussel filtration capacity in a $480 \mathrm{~km}$, Upper Mississippi River (UMR) segment, as a percentage of river discharge, is up to $1.4 \%$ at high flows, up to $4.4 \%$ at moderate flows and up to $12.2 \%$ during low flows (Newton et al. 2011). The mussels in this river segment collectively filter over 14 billion gallons of water, remove tons of biomass from the overlying water, and deposit tons of reduced $\mathrm{C}$ and nitrogen $(\mathrm{N})$ at the water-sediment interface each day (Newell 2004). The pocketbook mussel (Lampsilis cardium) and threeridge mussel (Amblema plicata) comprise up to $38 \%$ and $56 \%$ of the mussel biomass in the UMR, respectively (Newton et al. 2011). A habitat near Buffalo, Iowa, in UMR Pool 16, had mean densities of 1.56 L. cardium-m² and 7.18 A. plicata- $\mathrm{m}^{-2}$ that correlated with fine sediment diameters $\left(\mathrm{d}_{50}=0.300 \pm 0.121 \mathrm{~mm}\right)$ which were presumably influenced by mussel burrowing (Young 2006). Mussels live primarily buried in sediment, with their posterior end often flush with the sediment surface (Haag 2012), or slightly below the surface in soft sediments (Allen \& Vaughn 2009; Allen 1923; Matteson 1955). This positions adult freshwater mussels $6-10 \mathrm{~cm}$ into the sediment with tendencies toward more shallow burrowing during the spring and summer (Schwalb \& Pusch 2007). Extensive observations in the UMR concluded that A. plicata were often found with portions of their shell above the water-sediment interface, while L. cardium burrow a few $\mathrm{cm}$ into the sediment during the summer (Newton et al. 2015). Additionally, A. plicata often burrowed up to $2.5 \mathrm{~cm}$ vertically (Allen \& Vaughn 2009) in response to stressors while L. cardium moved more horizontally when stressed (Newton et al. 2015). Two common stressors, that happen to be created by the mussels 
68 themselves, are low dissolved oxygen (DO) and elevated ammonia $\left(\mathrm{NH}_{3}\right)$ and $\mathrm{NH}_{4}{ }^{+}(\mathrm{Bril}$ et al.

69 2017; Haag 2012). We hypothesize that this frequent vertical and horizontal movement by

70 mussels, many times as an indirect and/or direct response to their own waste production, has a

71 significant impact on porewater chemistry and microbiology in UMR sediments. especially for nutrients. A dense mussel population can sequester $2 \mathrm{~g} \mathrm{C}^{\text {day }}{ }^{-1} \mathrm{~m}^{-2}, 200 \mathrm{mg} \mathrm{N}$ day $^{-1}$ $\mathrm{m}^{-2}$, and $50 \mathrm{mg}$ phosphorus day ${ }^{-1} \mathrm{~m}^{-2}$ from river water into sediment (Strayer 2014). During the summer months, biodeposition-derived $\mathrm{N}$ from mussels was roughly $67 \% \mathrm{NH}_{4}^{+}, 28 \%$ amino acids, and 5\% urea (Bayne 1973). Mussel biodeposition accounted for up to $40 \%$ of total $\mathrm{N}$ demand in freshwaters and up to $74 \%$ of $\mathrm{N}$ in the food web, but was sometimes dampened (Atkinson et al. 2014) in high nutrient environments (Atkinson et al. 2014). Our previous work showed mussel burrowing and biodeposition, just below the water-sediment interface, increased porewater $\mathrm{NH}_{4}{ }^{+}$, nitrate $\left(\mathrm{NO}_{3}^{-}\right)$, nitrite $\left(\mathrm{NO}_{2}^{-}\right)$, and total organic $\mathrm{C}$ concentrations by $160 \%, 38 \%$, 40\%, and 26\%, respectively (Bril 2016; Bril et al. 2014). But, the experimental design of our previous work limited our ability to assess the effects of mussels on the broad microbial community that was transforming $\mathrm{N}$ simultaneously and, quite likely, synergistically. The UMR is an N-rich agro-ecosystem (Hill et al. 2011; Hill 2008; Houser \& Richardson 2010; Ikenberry et al. 2014; Schilling et al. 2015) shown to foster high microbial N transformations (Mason et al. 2016; Millar et al. 2015) potentially making the effects of mussels on a variety of $\mathrm{N}$-transforming bacteria and archaea more pronounced than in any other freshwater environment. The first step in transforming biologically active $\mathrm{N}$ is nitrification by aerobic ammonium oxidizing bacteria (AOB) (Figure 1, yellow arrows), such as the genera 
91 al. 2001; Hayatsu et al. 2008; Prosser et al. 2014), and aerobic ammonium oxidizing archaea

92 (AOA) in multiple candidate genera. AOB and AOA are metabolically diverse (Leininger et al.

93 2006) and serve a functionally important role of catalyzing the rate limiting step of nitrification

94 (Martens-Habbena et al. 2009) in various freshwater niches. For example, Candidatus

95 Nitrososphaera (phylum Thaumarchaetoa), a group of thermophilic AOA (Hatzenpichler et al.

96 2008), and AOB species in genera Nitrosospira and Nitrosococcus (Koper et al. 2004) can use

97 urea as an alternative source of $\mathrm{NH}_{4}{ }^{+}$(Spang et al. 2012). AOA often outnumber AOB (Prosser

$98 \&$ Nicol 2008) due to their ability to grow at $\mathrm{NH}_{4}{ }^{+}$concentrations below $10 \mathrm{nM}$ (Martens-

99 Habbena et al. 2009), compared to $10 \mu \mathrm{M}$ for some AOB species (Bollmann et al. 2002). In the

100 second step of nitrification, nitrite oxidizing bacteria (NOB), such as Nitrospira (phylum

101 Nitrospirae), and Nitrobacter, Nitrococcus, and Nitrospina (phylum Proteobacteria) (Prosser et

102 al. 2014), aerobically oxidize $\mathrm{NO}_{2}^{-}$to $\mathrm{NO}_{3}^{-}$(Figure 1, yellow arrows).

103 Nitrospira are the most abundant and diverse group of NOB and dominate numerous

104 habitats, ranging from freshwater sediment to engineered wastewater treatment plants (Daims et

al. 2015; Koch et al. 2015; Lucker et al. 2010). Furthermore, NOB species Nitrospira

106 moscoviensis and Nitrospira lenta can derive $\mathrm{NH}_{4}^{+}$from urea hydrolysis, provide $\mathrm{NH}_{4}{ }^{+}$to AOB,

107 and subsequently may oxidize $\mathrm{NO}_{2}^{-}$from $\mathrm{AOB}$ in a process deemed "reciprocal feeding of

108 nitrifiers" (Daims et al. 2015; Koch et al. 2015). Candidatus Nitrospira inopinata, can also use

109 urea as an alternative $\mathrm{NH}_{4}{ }^{+}$source (Daims et al. 2015) and has all the genes necessary for

110 complete ammonia oxidation (comammox) to $\mathrm{NO}_{3}^{-}$(van Kessel et al. 2015) (Figure 1, yellow

111 curved arrow). Denitrifiers complete the conventional $\mathrm{N}$-cycle by sequentially reducing $\mathrm{NO}_{3}{ }^{-}$to

112 nitric oxide (NO), nitrous oxide $\left(\mathrm{N}_{2} \mathrm{O}\right)$, and nitrogen gas in anoxic and high $\mathrm{C}$ environments

113 (Figure 1, blue arrows) (Hayatsu et al. 2008). 
A specialized group of bacteria in the phylum Planctomycetes, anaerobic ammonium oxidizing (anammox) bacteria, oxidize $\mathrm{NH}_{4}^{+}$, utilize $\mathrm{NO}_{2}{ }^{-}$as a terminal electron acceptor, and produce $\mathrm{N}_{2}$ gas (Kartal et al. 2011; Kuenen 2008) (Figure 1, gray arrows). Anammox bacteria thrive at the interface of oxic-anoxic conditions due to dependence on $\mathrm{NO}_{2}^{-}$production by $\mathrm{AOB}$ or AOA (Thamdrup 2012). Anammox and NOB compete for $\mathrm{NO}_{2}^{-}$in low substrate environments, and this is especially true for Nitrospira NOB, which share a homologous form of the key enzyme catalyzing $\mathrm{NO}_{2}^{-}$oxidation with anammox (Lucker et al. 2010). In another example, $N$. moscoviensis can adapt to a range of oxygen concentrations by coupling formate oxidation and $\mathrm{NO}_{3}{ }^{-}$reduction (Koch et al. 2015). Recently, an N-cycling enrichment culture revealed comammox bacteria co-occurring with anammox bacteria in the genus Candidatus Brocadia, presumably enhanced by the ability of commamox organisms to oxidize $\mathrm{NH}_{4}{ }^{+}$in low oxygen conditions $(<3.1 \mu \mathrm{M})$ (van Kessel et al. 2015). Nitrospira species, $N$. moscoviensis and "Ca. Nitrospira inopinata" in particular, are examples of NOB which harbor a unique ability to assist or compete with anammox for N-substrate in a variety of niches (Lucker et al. 2010).

$\mathrm{NH}_{4}{ }^{+}$fluxes into oxic sediment and $\mathrm{NO}_{2}{ }^{-}$limitations from denitrification (Thamdrup 2012; prokaryotic coupling of anaerobic oxidation of methane with denitrification (Raghoebarsing et 
137 oxyfera"(Ettwig et al. 2010) in phylum "NC10" (Ettwig et al. 2009; Luesken et al. 2011; Padilla

138 et al. 2016), and both are widespread in anoxic freshwater sediments (Deutzmann \& Schink

139 2011; Ding et al. 2016; Ettwig et al. 2009; Hu et al. 2009).

140 Mollusks have been shown to influence the diversity of microbial communities and

141 abundance of N-transforming microorganisms. For example, metagenomic profiling revealed a

142 marine California mussel (Mytilus californianus) shell provided a niche for N-and C-

143 transforming microorganism populations (Pfister et al. 2010), and a restored oyster reef enhanced

144 nitrification and denitrification rates greater than 10-fold (Kellogg et al. 2013). Furthermore, an

145 experimental microcosm study reported enhanced prokaryotic metabolic activity and diversity

146 following a biodeposition rate of $10 \mathrm{~g} \mathrm{~m}^{-2} \mathrm{~d}^{-1}$ of mussel feces and pseudofeces (Pollet et al.

147 2015). Additionally, clusters of the zebra mussel (Dreissena polymorpha) in a lake increased

148 heterotrophic bacteria density, activity, and diversity (Lohner et al. 2007). Since the impact of

149 native freshwater mussels on prokaryotic diversity and abundance in the UMR is largely

150 unknown, this study utilized targeted and non-targeted sequencing of the 16S rRNA gene to

151 determine how N-transforming microorganisms and microbial community structure differs in

152 sediments with mussels compared to sediments without mussels.

\section{Materials and Methods}

154 UMR sediments were collected within a dense, well-characterized mussel assemblage in the

155 Buffalo Habitat of UMR Pool 16 (Young 2006) (41.452804, -90.763299), and from a slightly up-

156 river location with no mussels $(41.451540,-90.753275)$ using a 3-inch diameter, hammer-driven,

157 acrylic tube (Batch 1 samples) or a 2-inch diameter, post-driver sediment sampler with a

158 polypropylene liner (Multi-Stage Sediment Sampler, Art's Manufacturing and Supply, Inc.,

159 American Falls, ID, USA; Batch 2 samples). Batch 1 sediment was used to identify the vertical 
160 distribution of anammox bacteria below freshwater mussels. For Batch 1, the acrylic tube for

161 each core ( $\mathrm{n}=3$ with-mussels) was penetrated at $1,3,5,7,11$, and $15 \mathrm{~cm}$ sediment depths with a

$1623 / 8^{\text {th }}$-inch diameter, ethanol flame-sterilized drill bit to enable sediment collection. In

163 comparison, Batch 2 sediment was used to characterize anammox abundance, microbial

164 diversity, and community structure in shallow sediments below mussels. For Batch 2, the

165 polypropylene liner for each sediment core ( $\mathrm{n}=5$ with-mussels, $\mathrm{n}=5$ no-mussels) was penetrated

166 at depths of $3 \mathrm{~cm}$ and $5 \mathrm{~cm}$. Sediment was sampled for DNA isolation (in quadruplicate) for a

167 combined sample size of $\mathrm{n}=20$ for $3 \mathrm{~cm}$ depth with-mussels, $\mathrm{n}=20$ for $5 \mathrm{~cm}$ depth with-mussels,

$168 \mathrm{n}=20$ for $3 \mathrm{~cm}$ depth without mussels, and $\mathrm{n}=20$ for $5 \mathrm{~cm}$ depth without mussels. Genomic DNA

169 was isolated from $0.25 \mathrm{~g}$ of each sediment sample (PowerSoil ${ }^{\circledR}$ DNA Isolation Kit, MoBio

170 Laboratories, Inc., Carlsbad, CA, USA) and stored at $-20^{\circ} \mathrm{C}$. Batch 2 Genomic DNA was used

171 for anammox-targeted qPCR ( $\mathrm{n}=20$ for each treatment) and 16S rRNA gene amplicon

172 sequencing $(\mathrm{n}=10$ for each treatment).

\section{Anammox 16 S rRNA gene quantification}

174 Microbial culture from a sidestream deammonification process (Hampton Roads Sanitation

175 District, Virginia Beach, VA) served as a source of anammox genetic material for qPCR standard 176 curve construction. PCR products (primers A483f (5'-GTCRGGAGTTADGAAATG-3') and 177 A684r (5'-ACCAGAAGTTCCACTCTC-3') (Sonthiphand \& Neufeld 2013)) of the anammox 178 16S rRNA gene was purified with Qiaquick PCR purification Kit (Qiagen Inc., Valencia, CA, 179 USA), and cloned into the pCR 2.1-TOPO ${ }^{\circ}$ vector using the TOPO ${ }^{\circ}$ TA cloning Kit 180 (Invitrogen Corp., Carlsbad, CA, USA). Clones were Sanger sequenced at the University of Iowa 181 Institute of Human Genetics with M13F (5'-TGTAAAACGACGGCCAGT-3') and M13R (5'182 CAGGAAACAGCTATGAC-3') primers to ensure anammox 16S rRNA PCR products were 
183 inserted into the vector. Nucleotide sequences were aligned using the Standard Nucleotide Basic

184 Local Alignment Search Tool (Altschul et al. 1997) (GenBank Accession: KU047953) and

185 classified as Candidatus Brocadiales (of the Planctomycetes phylum) with a 95\% confidence

186 threshold using RDP Naïve Bayesian rRNA Classifier Version 2.10 (Wang et al. 2007). Plasmid

187 DNA concentration was quantified with Qubit ${ }^{\circledR}$ Fluorometer 1.0 (Thermo Fisher Scientific,

188 Inc.), serially diluted, and used to construct qPCR calibration curves.

189 The anammox 16S rRNA gene from batches 1 and 2 was quantified (Wang et al. 2015)

190 with qPCR using QuantStudio ${ }^{\text {TM }} 7$ Flex Real-Time PCR System (Thermo Fisher Scientific, Inc.,

191 Waltham, MA, USA) with primers A483f and A684r (Sonthiphand \& Neufeld 2013) and

192 analyzed with QuantStudio ${ }^{\mathrm{TM}}$ Real-Time PCR Software (Thermo Fisher Scientific, Inc.). The

193 threshold cycle $\left(C_{t}\right)$ curves were satisfactory (slope $=-3.374$, $Y$-int $=36.702, R^{2}=0.998$, and

194 amplification efficiency $=97.99 \%$ ), and PCR product dissociation curves revealed singe peaks

195 centered at a melting temperature of $83^{\circ} \mathrm{C}$. The statistical significance of $16 \mathrm{~S}$ rRNA gene copies

196 was determined via a one-way, repeated measures analysis of variance (ANOVA) (SigmaPlot

197 13.0, Systat Software, Inc., Chicago, IL, USA) between the 4 treatment groups $(\mathrm{n}=20)$ following

198 a passed normality test $(\mathrm{p}=0.826$, Shapiro-Wilk) and an equal variance test $(\mathrm{p}=0.073$, Brown-

199 Forsythe). Pairwise multiple comparison procedures were completed via the Holm-Sidak method

200 with a significance level of 0.050 and a power of 0.990.

201 Non-targeted amplicon sequencing of the 16S rRNA gene

202 Batch 2 genomic DNA $(20 \mu \mathrm{L}, 1-50 \mathrm{ng} / \mu \mathrm{L})$ was analyzed by the Argonne National Laboratory,

203 Environmental Sample Preparation and Sequencing Facility (ESPSF) utilizing the Earth

204 Microbiome Project protocol (http://www.earthmicrobiome.org/emp-standard-protocols/16s/).

205 All samples were analyzed together in one batch. The v4 region of prokaryotic 16S rRNA gene 
206 (515F-806R) was amplified using the following conditions: 3 minutes at $94^{\circ} \mathrm{C}, 35$ cycles of $94^{\circ} \mathrm{C}$

207 for 45 seconds, $50^{\circ} \mathrm{C}$ for 60 seconds, and $72{ }^{\circ} \mathrm{C}$ for 90 seconds, followed by 10 minutes at $72{ }^{\circ} \mathrm{C}$

208 (Caporaso et al. 2012). The PCR mixture consisted of $13.0 \mu \mathrm{L}$ PCR grade water, $10.0 \mu \mathrm{L} 5$

209 PRIME HotMasterMix (Quanta Biosciences, Beverly, MA), $1.0 \mu \mathrm{L}$ genomic DNA, and $0.5 \mu \mathrm{L}$

210 forward and reverse primers $(10 \mu \mathrm{M})$. 16S rRNA gene amplicon libraries were sequenced by

211 ESPSF using Illumina MiSeq paired end reads (2x151 bp) (Caporaso et al. 2012) and uploaded

212 to MG-RAST (ID’s: 4705672.3-4705709.3) and NCBI (BioProject ID PRJNA374585).

213 Determining the operational taxonomic units ("OTUs") in each sample from the raw $16 \mathrm{~S}$

214 rRNA gene amplicon reads was accomplished using the default Quantitative Insights into

215 Microbial Ecology (QIIME) open-reference pipeline (Navas-Molina et al. 2013). Briefly, the

216 QIIME open-reference pipeline takes paired-end reads as input, which are then joined,

217 demultiplexed, filtered, and clustered into OTUs with uclust (Edgar 2010). Representative

218 sequences from each cluster were aligned (Caporaso et al. 2010) to GreenGenes 13.5 reference

219 database (DeSantis et al. 2006) with a 97\% similarity threshold. RDP classifier (Wang et al.

220 2007) was used for taxonomy assignment, PyNAST (Caporaso et al. 2010) was used for multiple

221 sequence alignment. Phylogenetic trees were constructed using FastTree2.1.3 with default

222 settings (Price et al. 2010). The OTU table from QIIME open reference picking

223 ('otu_table_mc2_w_tax_no_pynast_failures_json.biom' in the standard QIIME workflow) was

224 imported into R using the phyloseq package (McMurdie \& Holmes 2013) for downstream

225 analysis, along with the corresponding phylogenetic tree ('rep_set.tre') and a metadata mapping

226 file. These datasets were merged to create a single 'physeq' object representing the experiment.

227 Alpha-diversity was calculated on the unfiltered OTU abundance data using the Observed

228 species, Chao1 (Chao \& Chiu 2001), and Shannon (Li et al. 2011) metrics. Beta-diversity was 
229 calculated using a matrix of bray-curtis (Bray \& Curtis 1957) intersample distances and 230 ordination plots calculated with non-metric multidimensional scaling (NMDS). Differential

231 abundance analysis was carried out using the DESeq2 (Love et al. 2014) R package with default

232 settings (test type was "Wald," fit type was "parametric"). Translating physeq objects into a 233 compatible DESeq2 object was performed with the "phyloseq_to_deseq2" function. The

234 complete data analysis R script can be downloaded from the public github repository:

235 https://github.com/mchimenti/black_chimenti_just_phyloseq/blob/master/phyloseq.r.

Analysis at the OTU level provided a fine scale resolution for significant differences in microbial ecology between mussel and no mussel treatments. To put these results into a biological context, the genus-level OTU file was used to compare relative abundances for $\mathrm{N}$ cycle phylotypes. These groups include AOA genus Candidatus Nitrososphaera, nitrate-damo family “ANME-2d", NOB genus Nitrospira, anammox genus Candidatus Brocadia, AOB family Nitrosomonadaceae, and nitrite-damo phylum "NC10". Relative abundance counts for each Ncycle group was tested for statistical significance between treatments, using metadata groups "3 cm with-mussels" ( $\mathrm{n}=10)$, " $5 \mathrm{~cm}$ with-mussels" $(\mathrm{n}=10)$, , $3 \mathrm{~cm}$ no-mussels" $(\mathrm{n}=10)$, and " $5 \mathrm{~cm}$

244 no-mussels" (n=10). 1-way ANOVA's of each N-cycle group was performed using the KruskalWallis test $(\mathrm{p}<0.05)$ with Dunn's multiple correction test (Padj<0.05) (GraphPad Prism 7.0, La Jolla, CA). Similarly, multiple comparisons were made between all N-cycle phylotype groups tested using the Kruskal-Wallis test $(\mathrm{P}<0.0001)$ and Dunn's multiple comparison test $(\operatorname{Padj}<0.05)$.

\section{Results}


252 The targeted 16S rRNA gene data from Batch $1(\mathrm{n}=3$, with-mussels) indicated an anammox

253 bacterial gene copy maximum $\left(\sim 3 \times 10^{5}\right.$ copies $\mathrm{g}^{-1}$ sediment $)$ between $3 \mathrm{~cm}$ and $7 \mathrm{~cm}$ sediment

254 depth in the presence of mussels (Figure 2A). The Batch 1 data was normally distributed

255 between $1 \mathrm{~cm}$ and $15 \mathrm{~cm}$ (Shapiro-Wilk normality test, $\mathrm{W}$-statistic $=0.954, \mathrm{p}=0.773$ ). Only one

256 sediment core went beyond $7 \mathrm{~cm}$ leaving anammox bacterial gene copy data at $11 \mathrm{~cm}$ and $15 \mathrm{~cm}$

257 without replicates. The Batch 2 data ( $\mathrm{n}=20$ for $3 \mathrm{~cm}$ with-mussels, $\mathrm{n}=20$ for $5 \mathrm{~cm}$ with-mussels,

$258 \mathrm{n}=20$ for $3 \mathrm{~cm}$ no-mussels, $\mathrm{n}=20$ for $5 \mathrm{~cm}$ no-mussels) showed that anammox bacteria

259 experienced a 2.2-fold increase $(\mathrm{p}<0.001)$ at $3 \mathrm{~cm}$ with-mussels compared to the no-mussels

260 control (Figure 2B). The anammox gene copies measured at $5 \mathrm{~cm}$ were statistically

261 indistinguishable between the with-mussels and no-mussels treatments.

262 Non-targeted sequencing of the $16 \mathrm{~S}$ rRNA gene

263 Summing across all samples, a total of 2,103,661 amplicon sequences were analyzed and about

26476,000 unique OTUs were reported by QIIME. Of the unique OTUs, 18,777 had 10 or more

265 reads and 3,916 OTUs had counts exceeding 100 reads. Mussel bed samples had read counts of $45,290( \pm 15,271)$ at $3 \mathrm{~cm}$ sediment depth and 52,451 $( \pm 7,044)$ at $5 \mathrm{~cm}$ sediment depth, while nomussel samples had 48,920 $( \pm 7,517)$ read counts at $3 \mathrm{~cm}$ depth and $63,706( \pm 25,379)$ at $5 \mathrm{~cm}$ sediment depth (read depths depicted in Figure S1). The top phyla in mussel bed sediments were Proteobacteria (40.7\%), Nitrospirae (35.2\%), Chloroflexi (5.9\%), Euryarchaeota (5.0\%), Chlorobi (4.2\%), and Bacteroidetes (2.3\%). Proteobacteria decreased by about $6 \%$ with mussels while Nitrospirae increased by $10 \%$ with mussels. The most abundant taxonomic families in the Nitrospirae phylum were Thermodesulfovibrionaceae (55\%), "FW" (33\%), and Nitrospiraceae $(13 \%)$, and were $5 \%$ less, $3 \%$ and $2 \%$ greater than in no-mussel samples, respectively. With mussels, Proteobacteria taxonomic classes consisted of the following proportions: $68 \%$ 
275 Deltaproteobacteria (8\% less than without-mussels), 16\% Gammaproteobacteria, and 15\%

276 Betaproteobacteria. A majority of these Deltaproteobacteria OTUs were from "BPC076",

277 Desulfarculales, and Syntrophobacterales taxanomic orders, while orders Burkholderiales and

278 Xanthomonodales made up a majority of Betaproteobacteria and Gammaproteobacteria taxons.

279 Species richness was analyzed using three common measures: Observed species, Chao1

280 and Shannon indices ( $\mathrm{n}=20$ with-mussels and $\mathrm{n}=20$ without mussels). Together, the three

281 measures indicated a decrease in microbial community richness and evenness in the presence of

282 mussels as compared to sediments without mussels (Figure 3A). The observed decrease in alpha-

283 diversity reached significance for each of the three measures tested ( $p=0.0054$ or lower). A

284 similar result was obtained when calculating alpha-diversity measures in samples exclusively

285 from $3 \mathrm{~cm}(\mathrm{n}=10)$ or exclusively from $5 \mathrm{~cm}(\mathrm{n}=10)$ depths in the presence and absence of

286 mussels. However, the decrease in richness was more pronounced at $5 \mathrm{~cm}$ than at $3 \mathrm{~cm}$ depth

287 (Figures S2 and S3).

To compare intersample diversity in species abundances and community composition

289 ("beta diversity”), we employed NMDS scaling to accurately visualize, in 2D space, the higher-

290 order community structure between with-mussels and no-mussels samples (Figure 3B). The

291 NMDS model produced an excellent representation of the bray-curtis distances for all samples

292 (convergence in 20 iterations, stress 0.06; shepard plot shown in Figure S4). The beta diversity

293 clearly differentiated as a function of mussel presence, but not sediment depth (Figure 3B).

294 Taken together, these data show that mussel presence had a pronounced influence on the

295 microbial community evenness, richness, and composition within the sediment.

Differential abundances in OTUs did not reach significance for metadata values of

297 sediment depth or comparisons between sediment cores. On the other hand, there were numerous 
298

299

300

301

302

303

304

305

306

307

308

309

310

311

312

313

314

315

316

317

318

319

320

differences in OTU abundances when comparing sediment with mussels and without mussels.

We performed a differential abundance estimation with the DESeq2 R package using mussel

presence status ( $\mathrm{n}=20$ with-mussels, $\mathrm{n}=20$ no-mussels) as our covariate. 734 OTUs (or $0.94 \%$ of

the 77,288 OTUs tested) reached significance with a false discovery rate of 0.01 . The vast

majority of OTUs belonging to the phyla Gemmatimonadetes, Actinobacteria, Acidobacteria,

Plantomycetes, Chloroflexi, Firmicutes, Crenarcheota, and Verrucomicrobia decreased by at

least 4-fold in the presence of mussels. In contrast, Proteobacteria showed a marked decrease in

order Alphaproteobacteria, while showing mixed increasing and decreasing OTUs among Beta-,

Delta-, and Gammaproteobacteria. Phylum Nitrospirae also had 38 OTUs which were

differentially abundant with $\mathrm{p}$-adj $<0.001$. OTUs assigned to the GreenGenes taxonomic family

of "0319-6A21" were the most abundant among those OTUs increasing without mussels, while

families Thermodesulfovibrionaceae and "FW" were most abundant among those OTUs

increasing with mussels.

Many of the Nitrospirae taxons that increased without mussels did so from a smaller

average abundance (17 average counts for Nitrospira and up to 126 average counts for

Thermodesulfovibrionaceae) relative to those that were increased with mussels (209 average

counts for Nitrospira and up to 581 average counts for Thermodesulfovibrionaceae). This

explains the $10 \%$ increase in Nitrospirae abundance when summing across all samples with

mussels. Figure 4 shows the Log2FC categorized by phyla for OTUs with $p$-adj $<0.0001$ (to

enhance visual clarity). Significant differences within the Nitrospirae phylum were represented

by increases of genus "HB118" in family Thermodesulfovibrionaceae (2.0Log2FC from a mean

count of 52, $\mathrm{p}<0.001)$ and unclassified Nitrospira species $(0.8 \log 2 \mathrm{FC}$ from an average count of 209, p<0.001) with mussels. No-mussel treatments showed increases in genus "LCP-6" from 
321 family Thermodesulfovibrionaceae (3.6Log2FC from an average count of 126, $<<0.001$ ) and

322 unclassified Nitrospira species $(2.1 \log 2 \mathrm{FC}$ from an average count of $17, \mathrm{p}<0.001)$.

323 Despite seemingly even representation of phylum Thaumarchaeota between treatments,

324 unclassified species from Candidatus Nitrososphaera were enhanced from an average abundance

325 of $126(1.73 \mathrm{Log} 2 \mathrm{FC}, \mathrm{p}<0.001)$ without mussels, and AOA species, Candidatus Nitrososphaera

326 gargensis increased from an average count of $16(2.85 \log 2 \mathrm{FC}, \mathrm{p}<0.001)$ without mussels. One

327 OTU classified in the anammox genus, Candidatus Brocadia, increased from an average count of

$32817(3.72 \mathrm{Log} 2 \mathrm{FC}, \mathrm{p}<0.001)$ without mussels, while another OTU classified as an unknown

329 Candidatus Brocadia species increased from a mean count of 16 (1.2Log2FC, $\mathrm{p}=0.001)$ with-

330 mussels. Furthermore, OTUs belonging to the AOB family Nitrosomonadaceae increased from

331 an average abundance of $6(1.9 \log 2 \mathrm{FC}, \mathrm{p}<0.001)$ with mussels. Without mussels, taxonomic

332 groups capable of nitrite-damo, phylum "NC10", increased from average abundances up to 130

333 (4.4 Log2FC, $\mathrm{p}<0.001$ ), and nitrate-damo family “ANME-2d” increased from average

334 abundances up to $59(3.4 \log 2 \mathrm{FC}, \mathrm{p}<0.001)$. A summary of $\log 2 \mathrm{FC}$ values for OTUs relevant

335 to N-transformations are listed in Table S1.

$336 \quad$ N-cycle phylotypes were examined for statistically significant relative abundances between

337 treatments of mussel presence and sediment depth (Table 1). Candidatus Nitrososphaera

338 experienced a 2.6-fold decrease $(\mathrm{p}=0.047)$ with mussels at $5 \mathrm{~cm}$ sediment depth. ANME-2d was

3393 times greater $(\mathrm{p}=0.049)$ at $5 \mathrm{~cm}$ sediment depth without mussels, compared to $3 \mathrm{~cm}$ sediment

340 depth without mussels. Within the mussel bed, Nitrospira were 1.7 times greater $(\mathrm{p}=0.0497)$ at 3

$341 \mathrm{~cm}$ depth, and experienced a 1.9-fold increase $(\mathrm{p}=0.025)$ with mussels at $3 \mathrm{~cm}$ sediment depth

342 versus control. Candidatus Brocadia was 3 times greater $(\mathrm{p}=0.013)$ at $5 \mathrm{~cm}$ depth without

343 mussels versus $3 \mathrm{~cm}$ without mussels, and the $3 \mathrm{~cm}$ sediment showed a 2 -fold increase $(\mathrm{p}=0.002)$ 
344 with mussels versus control. Nitrosomonadaceae was 2.7 times greater $(p=0.015)$ at $3 \mathrm{~cm}$ with

345 mussels versus $5 \mathrm{~cm}$ depth with mussels.

346 Relative abundances of N-cycle phylotypes were compared within each treatment (Figure 5,

347 Boxes A, B, D, E) and between treatments (Figure 5, Boxes C, F, G-I). Within 3 cm sediment

348 samples with mussels (Figure 5, Box A), Nitrospira was statistically greater in abundance than

349 Candidatus Brocadia, and ANME-2d was less abundant than Nitrospira. Sediment without

350 mussels at $3 \mathrm{~cm}$ depth (Figure 5, Box B) contained statistically greater abundances of

351 Candidatus Nitrososphaera than Candidatus Brocadia, and greater Nitrospira abundances

352 compared to Candidatus Brocadia, Nitrosomonadaceae, and ANME-2d.

353 Relative abundance comparisons between mussel and no-mussel treatments at $3 \mathrm{~cm}$ depth

354 (Figure 5, Box C) showed that Candidatus Nitrososphaera was reduced in the mussel treatment,

355 while Nitrospira and Candidatus Brocadia were enhanced with mussels. Within mussel sediment

356 samples at $5 \mathrm{~cm}$ depth, Nitrospira was more abundant than Candidatus Brocadia, ANME-2d, and

357 Nitrosomonadaceae. (Figure 5, Box D). On the other hand, Candidatus Nitrososphaera and

358 Nitrospira were both more abundant than Nitrosomonadaceae without mussels at $5 \mathrm{~cm}$ sediment

359 depth (Figure 5, Box E). Comparing microbial communities at $5 \mathrm{~cm}$ depth between mussel and

360 no-mussel treatments (Figure 5, Box F) revealed that Candidatus Nitrososphaera was less

361 abundant with mussels versus the no-mussel population. Nitrospira and Nitrosomonadaceae

362 phylotypes were more prominent with mussels in shallow sediment depths (Figure 5, Box G).

363 Overall, Nitrospira made up larger proportions of microbial communities with and without

364 mussels compared to many N-cycle organisms, especially Candidatus Brocadia and

365 Nitrosomonadaceae (Figure 5, Box C, F, and G-I). Without mussels at $3 \mathrm{~cm}$ sediment depth,

366 Candidatus Brocadia made up a smaller proportion of the N-cycling microbial community, 
367 especially when compared to Candidatus Nitrososphaera, ANME-2d, NC10, and Nitrospira in

368 deeper sediments (Figure 5, Box H).

369 Discussion

370 Numerous studies have found Proteobacteria to be the most abundant phylum in freshwater

371 sediments (Bucci et al. 2014; Dai et al. 2016; Wakelin et al. 2008; Zeng et al. 2008; Zhang et al.

372 2015), sediments with mollusks (Fernandez et al. 2014; Lee et al. 2015), and also mollusk

373 microbiomes (Frischer et al. 2000; Neta et al. 2015; Ngangbam et al. 2015; Trabal et al. 2012).

374 Although our results showed Proteobacteria were the most abundant phylum, we observed a

375 decrease in Proteobacteria by $6 \%$ and an increase in Nitrospirae by $10 \%$ in the presence of

376 mussels. Families Thermodesulfovibrionaceae and "FW" accounted for many of the Nitrospirae

377 OTUs that increased with mussels and helps explain decreases in species richness for mussel bed 378 sediment.

379 Sediments contain the most phylogenetically diverse microbial communities (Lozupone $380 \&$ Knight 2007) and structure and diversity of soil microbial communities is often determined by 381 soil biogeochemistry (Fierer \& Jackson 2006), further supporting the impact mussels have on

382 biogeochemical cycling. In support of our hypothesis, our data indicated that mussel presence in 383 the UMR had a pronounced influence on the microbial community evenness, richness, and 384 composition within the sediment. The observed changes in sediment microbial community 385 structure and diversity showed mussels created a niche for specific microorganisms and may be 386 attributable to the diverse chemical composition of mussel biodeposits, mixing of sediment from 387 mussel burrowing, or the microbes living on mussels. Our findings of distinct microbial 388 communities in mussel bed sediment are corroborated by a study of the California mussel 
389 (Pfister et al. 2014) where taxonomic richness increased and taxa evenness increased following 390 the removal of mussels from a rocky shore habitat.

In contrast to our results of decreased microbial diversity with freshwater mussels,

392

394

research has shown invasive zebra mussels (Dreissena polymorpha) increased bacterial community diversity and richness (Lee et al. 2015), and metabolic diversity and activity in freshwater sediments (Lohner et al. 2007). Increased microbial diversity and activity has been attributed to the variety of $\mathrm{C}$ and $\mathrm{N}$ components in feces and pseudofeces, and also selects for the dominant microbial species (Lohner et al. 2007; Pollet et al. 2015). An experiment combining estuarine bivalve species ( $N$. virens, $M$. arenaria, and M. balthica) implicated mussel-induced changes in $\mathrm{O}_{2}, \mathrm{NH}_{4}{ }^{+}$and $\mathrm{NO}_{3}{ }^{-}$fluxes for the alteration of microbial community composition (Michaud et al. 2009). On the other hand, investigation of microbiota in Thick-shelled River Mussel (Unio crassus) beds did not find any difference in microorganism diversity, abundance, and composition (Richter et al. 2016). This may be explained by the drastic differences in the study site, with high mussel densities (23-433 mussels $/ \mathrm{m}^{2}$ ) and control plots containing low microbial diversities with mean species richness of 48 OTUs/sample with high evenness (Richter et al. 2016). The contrasting findings of microbial community diversity and composition indicate that mussel density and/or mollusk species may produce different responses by microorganism communities.

Additionally, alterations in sediment microbial community structure may arise from exposure to the mussel shell, tissues, or fecal microbiome. Mussel tissue and fecal material has been shown to contain less diverse microbiomes than the surrounding water and sediment for the zebra mussel (Frischer et al. 2000), tropical oyster (Crassostrea rhizophorae) (Neta et al. 2015), and marine mussel, Mytilus californianus (Frischer et al. 2000; Pfister et al. 2014). Some studies 
412 have attributed immediate increased sediment microbial activity to the mussel intestinal

413 microbiome (Grenz et al. 1990). Furthermore, mollusk biodeposition rates and biodeposit

414 chemical compositions are highly dependent on mollusk species (Hegaret et al. 2007; Tenore \&

415 Dunstan 1973), and food availability (Bril et al. 2017; Cranford et al. 2007; Vaughn \&

416 Hakenkamp 2001), so it makes sense that our results differ from studies with dissimilar mollusk

417 species, densities, and study location.

418 Changes in mussel bed sediment microbial communities was also likely enhanced by

419 mussel burrowing, because diffusion of substrates across the water-sediment interface is a

420 relatively slow process (Kristensen et al. 2012) and is increased by mollusk burrowing (Vaughn

421 \& Hakenkamp 2001), which ultimately affects microbial communities. For example, the burrow

422 of shrimp species Upogebia deltaura and Callianassa subterranean contained distinct bacterial

423 communities and a 3-fold increase in taxon richness (Laverock et al. 2010), and the estuarine

424 bivalve, C. fluminea, stimulated microbial diversity via bioturbation (Novais et al. 2016). It is

425 likely that UMR mussel bed sediments also experience the benefits from bioturbation, such as

426 sediment mixing (McCall et al. 1979) and aeration (Vaughn \& Hakenkamp 2001). Furthermore,

427 bioturbation has been linked to increased $\mathrm{NH}_{4}{ }^{+}$concentrations which alters the $\mathrm{N}$-transforming

428 microbial community (Chen \& Gu 2017), with greatest effects on bacteria growth found at 4 to 6

429 cm depth below the water-sediment interface (McCall et al. 1986).

$430 \quad$ N-cycle microbial community

431 Our research revealed an increase in anammox bacteria abundance $3 \mathrm{~cm}$ below the water-

432 sediment interface when mussels were present, shown for the anammox community using 433 anammox-targeted qPCR (2.2-fold increase) and for Candidatus Brocadia using non-targeted

434 16S rRNA gene amplicon sequencing (2-fold increase). The significance of agreement between 
435 these techniques is finding that increases in the genus Candidatus Brocadia are representative for 436 the anammox phylotype as a whole. Candidatus Brocadia may also make up a majority of the 437 anammox community in UMR sediment, as amplicon sequencing did not detect anammox 438 bacteria belonging to other genera. We are confident in these conclusions, as Candidatus 439 Brocadia is often the dominant anammox genus in freshwater sediments (Humbert et al. 2009; 440 Shen et al. 2016; Sonthiphand et al. 2014). One study showed that feeding of $\mathrm{NH}_{4}^{+}, \mathrm{NO}_{2}^{-}, \mathrm{NO}_{3}^{-}$, 441 and acetate led to an $80 \%$ enrichment of Candidatus 'Brocadia fulgida', signifying that B.

442 fulgida could outcompete anammox species in genera Candidatus Anammoxoglobus and 443 Candidatus Kuenenia, species Candidatus 'Brocadia anammoxidans', and even denitrifiers when 444 acetate is present (Kartal et al. 2008). This indicates that Candidatus Brocadia has a distinct 445 ecological niche and can utilize intermediates from anaerobic degradation of organic $\mathrm{C}$ to reduce $446 \mathrm{NO}_{3}{ }^{-}$(Kartal et al. 2008). Therefore, it is possible that a portion of our observed increases in 447 Candidatus Brocadia with mussels was attributable to $\mathrm{C}$ biodeposition in the UMR. 448 Our research also revealed a vertical distribution of anammox bacteria with higher 449 abundances near the sediment surface, which reflects the vertical distribution found in an 450 agricultural field (Shen et al. 2017), oxygen minimum zone (Galán et al. 2009), flooded paddy fields (Shen et al. 2017; Zhu et al. 2011), and an urban wetland (Shen et al. 2015). A vertical anammox distribution has been shown to coincide with $\mathrm{NH}_{4}{ }^{+}$presence and $\mathrm{NO}_{2}^{-}$production (Oshiki et al. 2016; Shen et al. 2014; Shen et al. 2015; Sun et al. 2014) and anammox "hotspots" occur in zones of low, but not entirely absent, $\mathrm{O}_{2}$ availability (Zhu et al. 2013). Anammox 455 abundance in freshwater sediment can range between $7 \times 10^{4}-8 \times 10^{6}$ gene copies $\mathrm{g}^{-1}$ sediment (Shen et al. 2016), or between $10^{6}-10^{7}$ gene copies $\mathrm{g}^{-1}$ sediment in peak $\mathrm{NO}_{2}^{-}$microniches at the oxic-anoxic interface (Nie et al. 2015; Shen et al. 2015; Zheng et al. 2016). Studies have shown 
458

459

460

461

462

463

464

465

466

467

468

469

470

471

472

473

474

475

476

477

478

479

480

anammox bacteria increase 1.5 to 2-fold within their niche (Nie et al. 2015; Zheng et al. 2016),

similar to our findings of a 2.2-fold increase in anammox bacteria $3 \mathrm{~cm}$ below the water-

sediment interfacewith mussels.

Co-occurrence of aerobic $\mathrm{NH}_{4}{ }^{+}$oxidation and anammox niches are likely due to linked

$\mathrm{NO}_{2}^{-}$oxidation and reduction, respectively (Shen et al. 2014). Interestingly, we found that

mussels also enhanced taxa from the AOB family Nitrosomonadaceae and the OTUs made up a greater proportion of mussel bed sediment populations near the water-sediment interface. To this point, the pacific oyster (C. gigas) was found to increase porewater $\mathrm{NH}_{4}{ }^{+}$and elevate the concentration of $\mathrm{NH}_{4}{ }^{+}$oxidizing microorganisms (Green et al. 2012). Furthermore, our previous research (Bril et al. 2014; Bril et al. 2017) showed elevated $\mathrm{NH}_{4}{ }^{+}$and $\mathrm{NO}_{2}{ }^{-}$in porewater of a similar depth below mussels. It makes sense that these groups of $\mathrm{N}$-transforming bacteria cooccur where their substrate microniches overlap, and is likely enhanced by mussels periodically aerating the sediment (Chen \& Gu 2017). Intermittent aeration has shown to enrich microbial cultures in $\mathrm{AOB}$ and anammox bacteria in engineered partial nitritation-anammox processes (Shannon et al. 2015; Yang et al. 2015), and similar to our findings, enriches the anammox genus Candidatus Brocadia (Shannon et al. 2015).

On the other hand, we saw a decrease in Candidatus Nitrososphaera (AOA) with mussels at $3 \mathrm{~cm}$ (1.7-fold) and $5 \mathrm{~cm}$ (2.6-fold) sediment depths. It makes sense that mussels suppress abundance of AOA since these organisms typically dominate sediment niches with low $\mathrm{NH}_{4}^{+}$ concentrations (Hatzenpichler 2012; Martens-Habbena et al. 2009). Furthermore, a group of OTUs suppressed by mussels were classified at the species level as Candidatus 'Nitrososphaera gargensis', which are partially inhibited by $\mathrm{NH}_{4}{ }^{+}$concentrations $(3.08 \mathrm{mM})$ much lower than AOB (Hatzenpichler 2012; Hatzenpichler et al. 2008; Nakagawa \& Takahashi 2015; Pester et al. 
481

482

483

484

485

486

487

488

489

490

491

492

493

494

495

496

497

498

499

500

501

502

2011). Furthermore, nitrifier niche partitioning studies using agricultural soil showed that AOB increased in abundance and activity following the addition of urine-derived $\mathrm{N}$, while AOA remained unchanged (Di et al. 2009; Hatzenpichler 2012; Jia \& Conrad 2009). Therefore, it is possible that mussel biodeposits and an increased flux of agriculturally-fed water into sediment by mussel burrowing enhanced porewater $\mathrm{NH}_{4}{ }^{+}$composition such that Nitrosomonadaceae out competed Candidatus Nitrososphaera. Our results agree with Chen et al.(2017), who found bioturbated sediment corresponded with a greater diversity of AOB and lower diversity of AOA microbial communities (Chen \& Gu 2017). On the other hand, our results of decreased abundance of Candidatus Nitrososphaera co-occurring with an increase in Nitrospira is in contrast to previous findings that these organisms may exhibit similar niche partitioning (Pester et al. 2011). For example, some species in Candidatus Nitrososphaera can adjust their metabolism for low oxygen availability (Zhalnina et al. 2014) and Nitrospira species are adapted to low oxygen concentrations (Maixner et al. 2006; Nowka et al. 2015; Zhalnina et al. 2014) and microoxic environments (Schramm et al. 2000). Alternatively, our detected increased abundance of Nitrospira may include species with a variety of environmental niches.

Some Nitrospira species have shown to occupy a niche at oxic-anoxic interfaces, in opposition to NOB with higher $\mathrm{O}_{2}$ tolerances such as those in genus Nitrobacter (Schramm et al. 2000). This supports our mussel-attributed increases in relative Nitrospira abundances (1.9-fold) at $3 \mathrm{~cm}$ sediment depths. Although we saw two different Nitrospira OTUs suppressed and enhanced by mussels, the mussel-enhanced OTUs had a larger mean abundance by about $12 \%$. Different NOB OTUs enhanced with and without mussels further suggests that mussel bed sediments harbor specific NOB strains sensitive to microoxic niches. Despite OTU variability, 
503 we can conclude that mussels enhance the Nitrospira phylotype, especially near the water-

504 sediment interface where Nitrospira were 1.7-times greater than deeper mussel bed depths.

505 On the other hand, we did not expect to see an increase in both NOB and anammox

506 phylotypes due to competition of $\mathrm{NO}_{2}{ }^{-}$as a substrate. The co-occurrence of Nitrospira and

507 anammox bacteria may be explained by the metabolic versatility of Nitrospira species, especially

508 if mussel-derived urea provided an additional source of $\mathrm{NH}_{3}$ and $\mathrm{NO}_{2}^{-}$via reciprocal feeding

509 between ammonia oxidizers and Nitrospira. Furthermore, these phylotypes have been shown to

510 coexist in an oxygen minimum zone, where anammox bacteria obtained a majority of $\mathrm{NO}_{2}^{-}$from

$511 \mathrm{NO}_{3}{ }^{-}$reducers (Lam et al. 2009). The similar effect size of mussels on Nitrospira (1.9-fold) and

512 Candidatus Brocadia (2-fold) at $3 \mathrm{~cm}$ depth suggests that mussels may exert similar influences

513 on the niches of these phylotypes. It is possible that these anammox and Nitrospira phylotypes

514 were functionally linked in shallow mussel bed sediment, which has been shown for microoxic

515 niches (van Kessel et al. 2015). Furthermore, it is possible that the Nitrospira co-occurring with

516 Candidatus Brocadia were Nitrospira species with the genetic potential for comammox, as a

517 fluorescence in-situ hybridization study confirmed the extensive aggregation of the 2 phylotypes

518 in hypoxic conditions $\left(<3.1 \mu \mathrm{M} \mathrm{O}_{2}\right)$ (van Kessel et al. 2015). Despite Nitrospira comammox

519 being identified in numerous aquatic environments (Chao et al. 2016; Daims et al. 2015; Pinto et

520 al. 2016), we cannot conclusively identify comammox without sequencing the ammonia

521 monooxygenase gene (Pinto et al. 2016; van Kessel et al. 2015).

522 In contrast to studies which found significant N-reduction on both a marine mussel

523 (Mytilus californianus) (Pfister et al. 2010) and a freshwater mussel (Limnoperna fortunei)

524 (Zhang et al. 2014), our results showed that mussels suppressed n-damo OTUs in phylum

525 "NC10" (2.1-fold) and family "ANME-2d" (1.8-fold). One study determined $\mathrm{NO}_{3}{ }^{-}$-damo was 
526 responsible for $\mathrm{NO}_{3}^{-}$reduction and anammox for $\mathrm{NO}_{2}^{-}$reductions in a bioreactor supplied with

$527 \mathrm{NH}_{4}^{+}, \mathrm{NO}_{2}^{-}, \mathrm{NO}_{3}{ }^{-}, \mathrm{CH}_{4}$, and anoxic conditions, thus concluding anammox outcompeted $\mathrm{NO}_{2}^{-}-$

528 damo (Hu et al. 2015). These findings make sense, because anammox bacteria have a higher

529 affinity for $\mathrm{NO}_{2}^{-}$(Luesken et al. 2011), anammox outperform n-damo in bioturbated sediments

530 with higher $\mathrm{NH}_{4}{ }^{+}$and lower $\mathrm{NO}_{2}{ }^{-}$and $\mathrm{NO}_{3}{ }^{-}$(Chen \& $\mathrm{Gu}$ 2017), and anammox and n-damo

531 communities have a competitive relationship in burrowed mangrove sediment (Chen \& Gu

532 2017). Furthermore, NC10 bacteria in a peatland were most prevalent at depths with porewater

$533 \mathrm{CH}_{4}$ concentrations near $300 \mu \mathrm{M}$, where $\mathrm{NO}_{3}{ }^{-}$consumption exceeds production, and in

534 completely anoxic conditions (Zhu et al. 2012). According to the literature, it makes sense that

535 we found UMR mussels enhanced Candidatus Brocadia and suppressed $\mathrm{NO}_{2}^{-}$reducing-NC10.

536 Perhaps n-damo organisms did not have a favorable niche in mussel bed sediment because

537 biodeposition products created an excess of $\mathrm{NH}_{4}{ }^{+}$in sediment porewater (Winkler et al. 2015), or

538 burrowing activity increased oxygen concentrations and made methane oxidation unfavorable

539 (van Bodegom et al. 2001). Our finding that no-mussel sediment contained 3 times more ANME-

540 2D in deeper, and presumably anoxic sediment, further suggests that mussels broaden the oxic-

541 anoxic interface niche (Chen \& Gu 2017; Luesken et al. 2011). However, we cannot extrapolate

542 these findings to all denitrifying organisms, since denitrifying species are sporadically distributed

543 among various taxonomic lineages, and are difficult to identify solely with16S rRNA amplicon

544 sequencing (Ishii et al. 2011).

545 Although we observed greater relative abundances of Nitrospira than Candidatus

546 Brocadia in a majority of treatments, both phylotypes increased by a factor of 2 with mussels at 3

$547 \mathrm{~cm}$ depth. No-mussel samples contained a significantly smaller proportion of Candidatus

548 Brocadia in shallow sediments compared to almost all N-transformers found in the deeper 
549 control sediments. Our phylotype-level analyses revealed similarities with the OTU-level

550 differential abundance comparisons. For example, phylotype comparisons showed ANME-2d

551 was less abundant than Nitrospira in $3 \mathrm{~cm}$ sediments with mussels, and Candidatus

552 Nitrososphaera was more abundant than Candidatus Brocadia in $3 \mathrm{~cm}$ sediment samples without 553 mussels. These results relate to DESeq2 OTU comparisons which found Candidatus Brocadia 554 and Nitrospira enhanced with mussels while ANME-2d and Candidatus Nitrososphaera were 555 suppressed with mussels.

556 Extending our focus beyond N-cycling organisms, we demonstrated that mussels

557 promoted a large effect size for OTUs classified as Thermodesulfovibrionaceae (Nitrospirales 558 order). In contrast to Nitrospira, the Nitrospirales genus Thermodesulfovibrio contains multiple 559 sulfate reducing species (Kirchman 2012; Sekiguchi et al. 2008) and can outcompete other 560 anaerobic organisms when sulfate is present (He et al. 2015). These findings are corroborated by 561 discoveries of significantly greater $\mathrm{C}$ and sulfate concentrations from mussel biodeposits and $56263 \%$ greater sulfate reduction in sediments with mussels (McKindsey et al. 2011). Biodeposition 563 products often lead to increasingly anoxic sediment and greater activity of anoxic

564 microorganisms (Kellogg et al. 2013; McKindsey et al. 2011), presumably due to consumption 565 of excretion products by oxygen-consuming microorganisms (Pollet et al. 2015). Interestingly, 566 Fdz-Polanco et al. (2001) observed simultaneous $\mathrm{N}$ and sulfate removal in an anaerobic 567 fluidized-bed reactor and proposed simultaneous anammox and sulfate reduction (Fdz-Polanco et 568 al. 2001). Coupled biological sulfate reduction and anammox reactions are metabolically feasible 569 (Schrum et al. 2009; Strous et al. 2002) and have been of interest in the recent history (Ali et al. 570 2013; Cai et al. 2010; Rikmann et al. 2016; Rios-Del Toro \& Cervantes 2016), therefore 571 warranting further research. Therefore, we showed that Thermodesulfovibrionaceae are 
572 significantly increased in the presence of mussels which may affect sulfate reduction (Mahmoudi

573 et al. 2015) in tandem with anammox reactions in UMR sediments.

As a whole, mussels do have an impact on microbial niches and lower the overall

575 community diversity. Mussel-influenced changes in microbiological diversity may have larger

576 ecosystem implications, such as macrobiota richness and diversity (Arribas et al. 2014;

577 Borthagaray \& Carranza 2007). Native freshwater mussels are capable of increasing macrobiota 578 diversity as a result of being keystone species (Hartmann et al. 2016) and ecosystem engineers

579 (Chowdhury et al. 2016; Lopes-Lima et al. 2014). Mussel biogeochemical hotspots can lead to a

580 bottom-up trophic cascade by enhancing $\mathrm{N}$ substrates normally limiting primary productivity,

581 ultimately leading to increased richness (Atkinson et al. 2013) and biodiversity (Allen et al.

582 2012) of higher trophic levels.

583 Conclusion

584 As far as we know, this is the first study to characterize freshwater mussel effects on microbial 585 community diversity, composition, and the vertical distribution of N-cycle microorganisms in the

586 UMR. qPCR of the anammox-specific 16S rRNA gene revealed an increase in anammox bacteria 587 abundance $3 \mathrm{~cm}$ below the water-sediment interface when mussels were present, and confirmed 588 anammox bacteria were normally distributed with depth. Non-targeted 16S rRNA gene amplicon 589 sequencing revealed mussel presence suppressed AOA (Candidatus Nitrososphaera) and that the 590 families Thermodesulfovibrionaceae and "FW" (Nitrospirales order) were overrepresented

591 among the enhanced OTUs with-mussels. Mussel bed sediment contained microbial 592 communities with 10\% greater Nitrospirae and 6\% fewer OTUs belonging to the phylum

593 Proteobacteria, which ultimately had a pronounced influence on microbial community evenness, 594 richness, and composition. This was indicated by lower observed species richness, Chao1 
595 diversity, Shannon diversity, and clustering of mussel samples in an NMDS analysis. We have

596 shown that native freshwater mussels affect niche differentiation of N-cycle microorganisms, as

597 evidenced by increased abundances of AOB family Nitrosomonadaceae, anammox genus

598 Candidatus Brocadia, and NOB genus Nitrospira, while exhibiting a decrease in AOA genus

599 Candidatus Nitrososphaera, and n-damo organisms in the phylum NC10 and family ANME-2d.

600 Co-occurring 2-fold increases in Candidatus Brocadia and Nitrospira in shallow sediment

601 suggests that mussels may enhance microbial niches at the interface of oxic-anoxic conditions,

602 presumably through biodeposition and burrowing. Ultimately, this study demonstrates the large

603 impact mussels have on biogeochemical N-cycling and ecosystem services in freshwater

604 agroecosystems. 
605

606

607

608

609

610

611

612

613

614

615

616

617

618

619

620

621

622

623

624

625

626

627

628

629

630

631

632

633

634

635

636

637

638

639

640

641

642

643

644

645

646

647

648

649

\section{References}

Aakra A, Utaker JB, Pommerening-Roser A, Koops HP, and Nes IF. 2001. Detailed phylogeny of ammoniaoxidizing bacteria determined by rDNA sequences and DNA homology values. International Journal of Systematic and Evolutionary Microbiology 51:2021-2030.

Ali M, Chai LY, Tang CJ, Zheng P, Min XB, Yang ZH, Xiong L, and Song YX. 2013. The Increasing Interest of ANAMMOX Research in China: Bacteria, Process Development, and Application. Biomed Research International. 10.1155/2013/134914

Allen DC, and Vaughn CC. 2009. Burrowing behavior of freshwater mussels in experimentally manipulated communities. Journal of the North American Benthological Society 28:93-100. 10.1899/07-170.1

Allen DC, Vaughn CC, Kelly JF, Cooper JT, and Engel MH. 2012. Bottom-up biodiversity effects increase resource subsidy flux between ecosystems. Ecology 93:2165-2174.

Allen WR. 1923. Studies of the Biology of Freshwater Mussels. II, The Nature and Degree of Response to Certain Physical and Chemical Stimuli. Ohio Journal of Science 23.

Altschul SF, Madden TL, Schaffer AA, Zhang JH, Zhang Z, Miller W, and Lipman DJ. 1997. Gapped BLAST and PSI-BLAST: a new generation of protein database search programs. Nucleic Acids Research 25:3389-3402. 10.1093/nar/25.17.3389

Arribas LP, Donnarumma L, Palomo MG, and Scrosati RA. 2014. Intertidal mussels as ecosystem engineers: their associated invertebrate biodiversity under contrasting wave exposures. Marine Biodiversity 44:203-211. 10.1007/s12526-014-0201-z

Atkinson CL, Kelly JF, and Vaughn CC. 2014. Tracing Consumer-Derived Nitrogen in Riverine Food Webs. Ecosystems 17:485-496. 10.1007/s10021-013-9736-2

Atkinson CL, Vaughn CC, Forshay KJ, and Cooper JT. 2013. Aggregated filter-feeding consumers alter nutrient limitation: consequences for ecosystem and community dynamics. Ecology 94:13591369.

Bayne BL. 1973. PHYSIOLOGICAL CHANGES IN MYTILUS-EDULIS-L INDUCED BY TEMPERATURE AND NUTRITIVE STRESS. Journal of the Marine Biological Association of the United Kingdom 53:39-58.

Bollmann A, Bar-Gilissen MJ, and Laanbroek HJ. 2002. Growth at low ammonium concentrations and starvation response as potential factors involved in niche differentiation among ammoniaoxidizing bacteria. Applied and Environmental Microbiology 68:4751-4757. 10.1128/aem.68.10.4751-4757.2002

Borthagaray Al, and Carranza A. 2007. Mussels as ecosystem engineers: Their contribution to species richness in a rocky littoral community. Acta Oecologica-International Journal of Ecology 31:243250. 10.1016/j.actao.2006.10.008

Bray JR, and Curtis JT. 1957. AN ORDINATION OF THE UPLAND FOREST COMMUNITIES OF SOUTHERN WISCONSIN. Ecological Monographs 27:326-349.

Bril JL, Kathryn; Just, Craig; Spak, Scott; Newton; Teresa. 2016. Simulated Mussel Mortality Thresholds as a Function of Mussel Biomass and Nutrient Loading. In Review.

Bril JS, Durst JJ, Hurley BM, Just CL, and Newton TJ. 2014. Sensor data as a measure of native freshwater mussel impact on nitrate formation and food digestion in continuous-flow mesocosms. Freshwater Science 33:417-424. 10.1086/675448

Bril JS, Langenfeld K, Just CL, Spak SN, and Newton TJ. 2017. Simulated mussel mortality thresholds as a function of mussel biomass and nutrient loading. PeerJ. DOI 10.7717/peerj.2838

Bucci J, Szempruch A, Caldwell J, Ellis J, and Levine J. 2014. Seasonal Changes in Microbial Community Structure in Freshwater Stream Sediment in a North Carolina River Basin. Diversity 6:18. 
650

651

652

653

654

655

656

657

658

659

660

661

662

663

664

665

666

667

668

669

670

671

672

673

674

675

676

677

678

679

680

681

682

683

684

685

686

687

688

689

690

691

692

693

694

695

696
Burrell PC, Phalen CM, and Hovanec TA. 2001. Identification of bacteria responsible for ammonia oxidation in freshwater aquaria. Applied and Environmental Microbiology 67:5791-5800. 10.1128/aem.67.12.5791-5800.2001

Cai J, Jiang JX, and Zheng P. 2010. Isolation and identification of bacteria responsible for simultaneous anaerobic ammonium and sulfate removal. Science China-Chemistry 53:645-650. 10.1007/s11426-010-0053-8

Caporaso JG, Bittinger K, Bushman FD, DeSantis TZ, Andersen GL, and Knight R. 2010. PyNAST: a flexible tool for aligning sequences to a template alignment. Bioinformatics 26:266-267. 10.1093/bioinformatics/btp636

Caporaso JG, Lauber CL, Walters WA, Berg-Lyons D, Huntley J, Fierer N, Owens SM, Betley J, Fraser L, Bauer M, Gormley N, Gilbert JA, Smith G, and Knight R. 2012. Ultra-high-throughput microbial community analysis on the Illumina HiSeq and MiSeq platforms. Isme Journal 6:1621-1624. 10.1038/ismej.2012.8

Chao A, and Chiu C-H. 2001. Nonparametric Estimation and Comparison of Species Richness. eLS: John Wiley \& Sons, Ltd.

Chao Y, Mao Y, Yu K, and Zhang T. 2016. Novel nitrifiers and comammox in a full-scale hybrid biofilm and activated sludge reactor revealed by metagenomic approach. Applied Microbiology and Biotechnology 100:8225-8237. 10.1007/s00253-016-7655-9

Chen J, and Gu J-D. 2017. Faunal Burrows Alter the Diversity, Abundance, and Structure of AOA, AOB, Anammox and n-Damo Communities in Coastal Mangrove Sediments. Microbial Ecology:1-17. 10.1007/s00248-017-0939-5

Chowdhury GW, Zieritz A, and Aldridge DC. 2016. Ecosystem engineering by mussels supports biodiversity and water clarity in a heavily polluted lake in Dhaka, Bangladesh. Freshwater Science 35:188-199. 10.1086/684169

Cranford PJ, Strain PM, Dowd M, Hargrave BT, Grant J, and Archambault MC. 2007. Influence of mussel aquaculture on nitrogen dynamics in a nutrient enriched coastal embayment. Marine Ecology Progress Series 347:61-78. 10.3354/meps06997

Dai Y, Yang YY, Wu Z, Feng QY, Xie SG, and Liu Y. 2016. Spatiotemporal variation of planktonic and sediment bacterial assemblages in two plateau freshwater lakes at different trophic status. Applied Microbiology and Biotechnology 100:4161-4175. 10.1007/s00253-015-7253-2

Daims H, Lebedeva EV, Pjevac P, Han P, Herbold C, Albertsen M, Jehmlich N, Palatinszky M, Vierheilig J, Bulaev A, Kirkegaard RH, von Bergen M, Rattei T, Bendinger B, Nielsen PH, and Wagner M. 2015. Complete nitrification by Nitrospira bacteria. Nature 528:504-+. 10.1038/nature16461

DeSantis TZ, Hugenholtz P, Larsen N, Rojas M, Brodie EL, Keller K, Huber T, Dalevi D, Hu P, and Andersen GL. 2006. Greengenes, a chimera-checked 16S rRNA gene database and workbench compatible with ARB. Applied and Environmental Microbiology 72:5069-5072. 10.1128/aem.03006-05

Deutzmann JS, and Schink B. 2011. Anaerobic Oxidation of Methane in Sediments of Lake Constance, an Oligotrophic Freshwater Lake. Applied and Environmental Microbiology 77:4429-4436. 10.1128/aem.00340-11

Di HJ, Cameron KC, Shen JP, Winefield CS, O/'Callaghan M, Bowatte S, and He JZ. 2009. Nitrification driven by bacteria and not archaea in nitrogen-rich grassland soils. Nature Geosci 2:621-624. http://www.nature.com/ngeo/journal/v2/n9/suppinfo/ngeo613 S1.html

Ding J, Fu L, Ding ZW, Lu YZ, Cheng SH, and Zeng RJ. 2016. Experimental evaluation of the metabolic reversibility of ANME-2d between anaerobic methane oxidation and methanogenesis. Applied Microbiology and Biotechnology 100:6481-6490. 10.1007/s00253-016-7475-y

Edgar RC. 2010. Search and clustering orders of magnitude faster than BLAST. Bioinformatics 26:24602461. 10.1093/bioinformatics/btq461 
697

698

699

700

701

702

703

704

705

706

707

708

709

710

711

712

713

714

715

716

717

718

719

720

721

722

723

724

725

726

727

728

729

730

731

732

733

734

735

736

737

738

739

740

741

Ettwig KF, Butler MK, Le Paslier D, Pelletier E, Mangenot S, Kuypers MMM, Schreiber F, Dutilh BE, Zedelius J, de Beer D, Gloerich J, Wessels HJCT, van Alen T, Luesken F, Wu ML, van de PasSchoonen KT, Op den Camp HJM, Janssen-Megens EM, Francoijs K-J, Stunnenberg H, Weissenbach J, Jetten MSM, and Strous M. 2010. Nitrite-driven anaerobic methane oxidation by oxygenic bacteria. Nature 464:543-548. http://www.nature.com/nature/journal/v464/n7288/suppinfo/nature08883 S1.html

Ettwig KF, van Alen T, van de Pas-Schoonen KT, Jetten MSM, and Strous M. 2009. Enrichment and Molecular Detection of Denitrifying Methanotrophic Bacteria of the NC10 Phylum. Applied and Environmental Microbiology 75:3656-3662. 10.1128/aem.00067-09

Fdz-Polanco F, Fdz-Polanco M, Fernandez N, Urueña MA, Garcia PA, and Villaverde S. 2001. New process for simultaneous removal of nitrogen and sulphur under anaerobic conditions. Water Research 35:1111-1114. http://dx.doi.org/10.1016/S0043-1354(00)00474-7

Fernandez NT, Mazon-Suastegui JM, Vazquez-Juarez R, Ascencio-Valle F, and Romero J. 2014. Changes in the composition and diversity of the bacterial microbiota associated with oysters (Crassostrea corteziensis, Crassostrea gigas and Crassostrea sikamea) during commercial production. Fems Microbiology Ecology 88:69-83. 10.1111/1574-6941.12270

Fierer N, and Jackson RB. 2006. The diversity and biogeography of soil bacterial communities.

Proceedings of the National Academy of Sciences of the United States of America 103:626-631. 10.1073/pnas.0507535103

Frischer ME, Nierzwicki-Bauer SA, Parsons RH, Vathanodorn K, and Waitkus KR. 2000. Interactions between zebra mussels (Dreissena polymorpha) and microbial communities. Canadian Journal of Fisheries and Aquatic Sciences 57:591-599. 10.1139/cjfas-57-3-591

Galán A, Molina V, Thamdrup B, Woebken D, Lavik G, Kuypers MMM, and Ulloa O. 2009. Anammox bacteria and the anaerobic oxidation of ammonium in the oxygen minimum zone off northern Chile. Deep Sea Research Part II: Topical Studies in Oceanography 56:1021-1031. http://dx.doi.org/10.1016/j.dsr2.2008.09.016

Green DS, Boots B, and Crowe TP. 2012. Effects of Non-Indigenous Oysters on Microbial Diversity and Ecosystem Functioning. Plos One 7. 10.1371/journal.pone.0048410

Grenz C, Hermin MN, Baudinet D, and Daumas R. 1990. INSITU BIOCHEMICAL AND BACTERIAL VARIATION OF SEDIMENTS ENRICHED WITH MUSSEL BIODEPOSITS. Hydrobiologia 207:153-160. $10.1007 /$ bf00041452

Haag WR. 2012. North American Freshwater Mussels: Natural History, Ecology, and Conservation. New York, NY: Cambridge University Press.

Haroon MF, Hu S, Shi Y, Imelfort M, Keller J, Hugenholtz P, Yuan Z, and Tyson GW. 2013. Anaerobic oxidation of methane coupled to nitrate reduction in a novel archaeal lineage. Nature 500:567570. $10.1038 /$ nature12375

\section{http://www.nature.com/nature/journal/v500/n7464/abs/nature12375.html\#supplementary- information}

Hartmann JT, Beggel S, Auerswald K, Stoeckle BC, and Geist J. 2016. Establishing mussel behavior as a biomarker in ecotoxicology. Aquatic Toxicology 170:279-288. 10.1016/j.aquatox.2015.06.014

Hatzenpichler R. 2012. Diversity, Physiology, and Niche Differentiation of Ammonia-Oxidizing Archaea. Applied and Environmental Microbiology 78:7501-7510. 10.1128/aem.01960-12

Hatzenpichler R, Lebedeva EV, Spieck E, Stoecker K, Richter A, Daims H, and Wagner M. 2008. A moderately thermophilic ammonia-oxidizing crenarchaeote from a hot spring. Proceedings of the National Academy of Sciences 105:2134-2139. 10.1073/pnas.0708857105 
742

743

744

745

746

747

748

749

750

751

752

753

754

755

756

757

758

759

760

761

762

763

764

765

766

767

768

769

770

771

772

773

774

775

776

777

778

779

780

781

782

783

784

785

786

787

788
Hayatsu M, Tago K, and Saito M. 2008. Various players in the nitrogen cycle: Diversity and functions of the microorganisms involved in nitrification and denitrification. Soil Science and Plant Nutrition 54:33-45. 10.1111/j.1747-0765.2007.00195.x

He SM, Malfatti SA, McFarland JW, Anderson FE, Pati A, Huntemann M, Tremblay J, del Rio TG, Waldrop MP, Windham-Myers L, and Tringe SG. 2015. Patterns in Wetland Microbial Community Composition and Functional Gene Repertoire Associated with Methane Emissions. Mbio 6. 10.1128/mBio.00066-15

Hegaret H, Wikfors GH, and Shumway SE. 2007. Diverse feeding responses of five species of bivalve mollusc when exposed to three species of harmful algae. Journal of Shellfish Research 26:549559. 10.2983/0730-8000(2007)26[549:dfrofs]2.0.co;2

Hill BH, Bolgrien DW, Herlihy AT, Jicha TM, and Angradi TR. 2011. A Synoptic Survey of Nitrogen and Phosphorus in Tributary Streams and Great Rivers of the Upper Mississippi, Missouri, and Ohio River Basins. Water Air and Soil Pollution 216:605-619. 10.1007/s11270-010-0556-0

Hill BH, C. M. Elonen, T. M. Jicha, and D. W. Bolgrien. 2008. Nutrient Chemistry and Microbial Activity in the Upper Mississippi River Basin: Stoichiometry and Downstream Patterns. American Water Resources Association Annual Meeting. New Orleans, LA: National Health and Environmental Effects Research Laboratory.

Houser JN, and Richardson WB. 2010. Nitrogen and phosphorus in the Upper Mississippi River: transport, processing, and effects on the river ecosystem. Hydrobiologia 640:71-88. 10.1007/s10750-009-0067-4

Hu S, Zeng RJ, Haroon MF, Keller J, Lant PA, Tyson GW, and Yuan Z. 2015. A laboratory investigation of interactions between denitrifying anaerobic methane oxidation (DAMO) and anammox processes in anoxic environments. Scientific Reports 5:8706. 10.1038/srep08706

Hu SH, Zeng RJ, Burow LC, Lant P, Keller J, and Yuan ZG. 2009. Enrichment of denitrifying anaerobic methane oxidizing microorganisms. Environmental Microbiology Reports 1:377-384. 10.1111/j.1758-2229.2009.00083.x

Humbert S, Tarnawski S, Fromin N, Mallet M-P, Aragno M, and Zopfi J. 2009. Molecular detection of anammox bacteria in terrestrial ecosystems: distribution and diversity. ISME J 4:450-454. http://www.nature.com/ismej/journal/v4/n3/suppinfo/ismej2009125s1.html

Ikenberry CD, Soupir ML, Schilling KE, Jones CS, and Seeman A. 2014. Nitrate-Nitrogen Export: Magnitude and Patterns from Drainage Districts to Downstream River Basins. Journal of Environmental Quality 43:2024-2033. 10.2134/jeq2014.05.0242

Ishii S, Ashida N, Otsuka S, and Senoo K. 2011. Isolation of Oligotrophic Denitrifiers Carrying Previously Uncharacterized Functional Gene Sequences. Applied and Environmental Microbiology 77:338342. 10.1128/aem.02189-10

Jia ZJ, and Conrad R. 2009. Bacteria rather than Archaea dominate microbial ammonia oxidation in an agricultural soil. Environmental Microbiology 11:1658-1671. 10.1111/j.1462-2920.2009.01891.x

Kartal B, Maalcke WJ, de Almeida NM, Cirpus I, Gloerich J, Geerts W, den Camp H, Harhangi HR, JanssenMegens EM, Francoijs KJ, Stunnenberg HG, Keltjens JT, Jetten MSM, and Strous M. 2011. Molecular mechanism of anaerobic ammonium oxidation. Nature 479:127-U159. 10.1038/nature10453

Kartal B, van Niftrik L, Rattray J, van de Vossenberg JLCM, Schmid MC, Sinninghe Damsté J, Jetten MSM, and Strous M. 2008. Candidatus 'Brocadia fulgida': an autofluorescent anaerobic ammonium oxidizing bacterium. Fems Microbiology Ecology 63:46-55. 10.1111/j.1574-6941.2007.00408.x

Kellogg ML, Cornwell JC, Owens MS, and Paynter KT. 2013. Denitrification and nutrient assimilation on a restored oyster reef. Marine Ecology Progress Series 480:1-19. 10.3354/meps10331

Kirchman DL. 2012. Processes in Microbial Ecology. 
789

790

791

792

793

794

795

796

797

798

799

800

801

802

803

804

805

806

807

808

809

810

811

812

813

814

815

816

817

818

819

820

821

822

823

824

825

826

827

828

829

830

831

832

833

834

Koch H, Lücker S, Albertsen M, Kitzinger K, Herbold C, Spieck E, Nielsen PH, Wagner M, and Daims H. 2015. Expanded metabolic versatility of ubiquitous nitrite-oxidizing bacteria from the genus Nitrospira. Proceedings of the National Academy of Sciences 112:11371-11376. 10.1073/pnas.1506533112

Koper TE, El-Sheikh AF, Norton JM, and Klotz MG. 2004. Urease-Encoding Genes in Ammonia-Oxidizing Bacteria. Applied and Environmental Microbiology 70:2342-2348. 10.1128/aem.70.4.23422348.2004

Kristensen E, Penha-Lopes G, Delefosse M, Valdemarsen T, Quintana CO, and Banta GT. 2012. What is bioturbation? The need for a precise definition for fauna in aquatic sciences. Marine Ecology Progress Series 446:285-302. 10.3354/meps09506

Kuenen JG. 2008. Anammox bacteria: from discovery to application. Nature Reviews Microbiology 6:320326. 10.1038/nrmicro1857

Lam P, Lavik G, Jensen MM, van de Vossenberg J, Schmid M, Woebken D, Gutiérrez D, Amann R, Jetten MSM, and Kuypers MMM. 2009. Revising the nitrogen cycle in the Peruvian oxygen minimum zone. Proceedings of the National Academy of Sciences 106:4752-4757. 10.1073/pnas.0812444106

Laverock B, Smith CJ, Tait K, Osborn AM, Widdicombe S, and Gilbert JA. 2010. Bioturbating shrimp alter the structure and diversity of bacterial communities in coastal marine sediments. Isme Journal 4:1531-1544. 10.1038/ismej.2010.86

Lee PO, McLellan SL, Graham LE, and Young EB. 2015. Invasive dreissenid mussels and benthic algae in Lake Michigan: characterizing effects on sediment bacterial communities. Fems Microbiology Ecology 91:1-12. 10.1093/femsec/fiu001

Leininger S, Urich T, Schloter M, Schwark L, Qi J, Nicol GW, Prosser JI, Schuster SC, and Schleper C. 2006. Archaea predominate among ammonia-oxidizing prokaryotes in soils. Nature 442:806-809. 10.1038/nature04983

Li M, Cao HL, Hong YG, and Gu JD. 2011. Seasonal Dynamics of Anammox Bacteria in Estuarial Sediment of the Mai Po Nature Reserve Revealed by Analyzing the 16S rRNA and Hydrazine Oxidoreductase (hzo) Genes. Microbes and Environments 26:15-22. 10.1264/jsme2.ME10131

Lohner RN, Sigler V, Mayer CM, and Balogh C. 2007. A comparison of the benthic bacterial communities within and surrounding Dreissena clusters in lakes. Microbial Ecology 54:469-477. 10.1007/s00248-007-9211-8

Lopes-Lima M, Teixeira A, Froufe E, Lopes A, Varandas S, and Sousa R. 2014. Biology and conservation of freshwater bivalves: past, present and future perspectives. Hydrobiologia 735:1-13. 10.1007/s10750-014-1902-9

Love MI, Huber W, and Anders S. 2014. Moderated estimation of fold change and dispersion for RNAseq data with DESeq2. Genome Biology 15. 10.1186/s13059-014-0550-8

Lozupone CA, and Knight R. 2007. Global patterns in bacterial diversity. Proceedings of the National Academy of Sciences of the United States of America 104:11436-11440. 10.1073/pnas.0611525104

Lucker S, Wagner M, Maixner F, Pelletier E, Koch H, Vacherie B, Rattei T, Damste JSS, Spieck E, Le Paslier D, and Daims H. 2010. A Nitrospira metagenome illuminates the physiology and evolution of globally important nitrite-oxidizing bacteria. Proceedings of the National Academy of Sciences of the United States of America 107:13479-13484. 10.1073/pnas.1003860107

Luesken FA, Sánchez J, van Alen TA, Sanabria J, Op den Camp HJM, Jetten MSM, and Kartal B. 2011. Simultaneous Nitrite-Dependent Anaerobic Methane and Ammonium Oxidation Processes. Applied and Environmental Microbiology 77:6802-6807. 10.1128/aem.05539-11 
835

836

837

838

839

840

841

842

843

844

845

846

847

848

849

850

851

852

853

854

855

856

857

858

859

860

861

862

863

864

865

866

867

868

869

870

871

872

873

874

875

876

877

878

879

880

881

Mahmoudi N, Robeson MS, Castro HF, Fortney JL, Techtmann SM, Joyner DC, Paradis CJ, Pfiffner SM, and Hazen TC. 2015. Microbial community composition and diversity in Caspian Sea sediments. Fems Microbiology Ecology 91. 10.1093/femsec/fiu013

Maixner F, Noguera DR, Anneser B, Stoecker K, Wegl G, Wagner M, and Daims H. 2006. Nitrite concentration influences the population structure of Nitrospira-like bacteria. Environmental Microbiology 8:1487-1495. 10.1111/j.1462-2920.2006.01033.x

Martens-Habbena W, Berube PM, Urakawa H, de la Torre JR, and StahI DA. 2009. Ammonia oxidation kinetics determine niche separation of nitrifying Archaea and Bacteria. Nature 461:976-U234. $10.1038 /$ nature 08465

Mason OU, Canter EJ, Gillies LE, Paisie TK, and Roberts BJ. 2016. Mississippi River Plume Enriches Microbial Diversity in the Northern Gulf of Mexico. Frontiers in Microbiology 7. 10.3389/fmicb.2016.01048

Matteson MR. 1955. Studies on the Natural History of the Unionidae. The American Midland Naturalist 53:126-145. 10.2307/2422303

McCall PL, Matisoff G, and Tevesz MJS. 1986. THE EFFECTS OF A UNIONID BIVALVE ON THE PHYSICAL, CHEMICAL, AND MICROBIAL PROPERTIES OF COHESIVE SEDIMENTS FROM LAKE ERIE. American Journal of Science 286:127-159.

McCall PL, Tevesz MJS, and Schwelgien SF. 1979. Sediment Mixing by Lampsilis Radiata Siliquoidea (Mollusca) from Western Lake Erie. Journal of Great Lakes Research 5:105-111. http://dx.doi.org/10.1016/S0380-1330(79)72135-6

McKindsey CW, Archambault P, Callier MD, and Olivier F. 2011. Influence of suspended and off-bottom mussel culture on the sea bottom and benthic habitats: a review. Canadian Journal of ZoologyRevue Canadienne De Zoologie 89:622-646. 10.1139/z11-037

McMurdie PJ, and Holmes S. 2013. phyloseq: An R Package for Reproducible Interactive Analysis and Graphics of Microbiome Census Data. Plos One 8. 10.1371/journal.pone.0061217

Michaud E, Desrosiers G, Aller RC, Mermillod-Blondin F, Sundby B, and Stora G. 2009. Spatial interactions in the Macoma balthica community control biogeochemical fluxes at the sedimentwater interface and microbial abundances. Journal of Marine Research 67:43-70.

Millar JJ, Payne JT, Ochs CA, and Jackson CR. 2015. Particle-associated and cell-free extracellular enzyme activity in relation to nutrient status of large tributaries of the Lower Mississippi River. Biogeochemistry 124:255-271. 10.1007/s10533-015-0096-1

Nakagawa T, and Takahashi R. 2015. Nitrosomonas stercoris sp. nov., a Chemoautotrophic AmmoniaOxidizing Bacterium Tolerant of High Ammonium Isolated from Composted Cattle Manure. Microbes and Environments 30:221-227. 10.1264/jsme2.ME15072

Navas-Molina JA, Peralta-Sanchez JM, Gonzalez A, McMurdie PJ, Vazquez-Baeza Y, Xu ZJ, Ursell LK, Lauber C, Zhou HW, Song SJ, Huntley J, Ackermann GL, Berg-Lyons D, Holmes S, Caporaso JG, and Knight R. 2013. Advancing Our Understanding of the Human Microbiome Using QIIME. In: DeLong EF, ed. Microbial Metagenomics, Metatranscriptomics, and Metaproteomics, 371-444.

Neta MTS, Maciel BM, Lopes ATS, Marques ELS, Rezende RP, and Boehs G. 2015. Microbiological quality and bacterial diversity of the tropical oyster Crassostrea rhizophorae in a monitored farming system and from natural stocks. Genetics and Molecular Research 14:15754-15768. 10.4238/2015.December.1.27

Newell RIE. 2004. Ecosystem influences of natural and cultivated populations of suspension-feeding bivalve molluscs: A review. Journal of Shellfish Research 23:51-61.

Newton TJ, Zigler SJ, and Gray BR. 2015. Mortality, movement and behaviour of native mussels during a planned water-level drawdown in the Upper Mississippi River. Freshwater Biology 60:1-15. 10.1111/fwb.12461 
882

883

884

885

886

887

888

889

890

891

892

893

894

895

896

897

898

899

900

901

902

903

904

905

906

907

908

909

910

911

912

913

914

915

916

917

918

919

920

921

922

923

924

925

926

927

Newton TJ, Zigler SJ, Rogala JT, Gray BR, and Davis M. 2011. Population assessment and potential functional roles of native mussels in the Upper Mississippi River. Aquatic Conservation-Marine and Freshwater Ecosystems 21:122-131. 10.1002/aqc.1170

Ngangbam AK, Baten A, Waters DLE, Whalan S, and Benkendorff K. 2015. Characterization of Bacterial Communities Associated with the Tyrian Purple Producing Gland in a Marine Gastropod. Plos One 10. 10.1371/journal.pone.0140725

Nie SA, Li H, Yang XR, Zhang ZJ, Weng BS, Huang FY, Zhu GB, and Zhu YG. 2015. Nitrogen loss by anaerobic oxidation of ammonium in rice rhizosphere. Isme Journal 9:2059-2067. 10.1038/ismej.2015.25

Novais A, Souza AT, Ilarri M, Pascoal C, and Sousa R. 2016. Effects of the invasive clam Corbicula fluminea (Muller, 1774) on an estuarine microbial community. Science of the Total Environment 566:1168-1175. 10.1016/j.scitotenv.2016.05.167

Nowka B, Daims H, and Spieck E. 2015. Comparison of Oxidation Kinetics of Nitrite-Oxidizing Bacteria: Nitrite Availability as a Key Factor in Niche Differentiation. Applied and Environmental Microbiology 81:745-753. 10.1128/aem.02734-14

Oshiki M, Satoh H, and Okabe S. 2016. Ecology and physiology of anaerobic ammonium oxidizing bacteria. Environmental Microbiology 18:2784-2796. 10.1111/1462-2920.13134

Padilla CC, Bristow LA, Sarode N, Garcia-Robledo E, Gomez Ramirez E, Benson CR, Bourbonnais A, Altabet MA, Girguis PR, Thamdrup B, and Stewart FJ. 2016. NC10 bacteria in marine oxygen minimum zones. ISME J 10:2067-2071. 10.1038/ismej.2015.262

Pester M, Schleper C, and Wagner M. 2011. The Thaumarchaeota: an emerging view of their phylogeny and ecophysiology. Current Opinion in Microbiology 14:300-306.

http://dx.doi.org/10.1016/j.mib.2011.04.007

Pfister CA, Gilbert JA, and Gibbons SM. 2014. The role of macrobiota in structuring microbial communities along rocky shores. Peerj 2. 10.7717/peerj.631

Pfister CA, Meyer F, and Antonopoulos DA. 2010. Metagenomic Profiling of a Microbial Assemblage Associated with the California Mussel: A Node in Networks of Carbon and Nitrogen Cycling. Plos One 5. 10.1371/journal.pone.0010518

Pinto AJ, Marcus DN, Ijaz UZ, Bautista-de lose Santos QM, Dick GJ, and Raskin L. 2016. Metagenomic Evidence for the Presence of Comammox Nitrospira-Like Bacteria in a Drinking Water System. mSphere 1:e00054-00015. 10.1128/mSphere.00054-15

Pollet T, Cloutier O, Nozais C, McKindsey CW, and Archambault P. 2015. Metabolic Activity and Functional Diversity Changes in Sediment Prokaryotic Communities Organically Enriched with Mussel Biodeposits. Plos One 10. 10.1371/journal.pone.0123681

Price MN, Dehal PS, and Arkin AP. 2010. FastTree 2-Approximately Maximum-Likelihood Trees for Large Alignments. Plos One 5. 10.1371/journal.pone.0009490

Prosser JI, Head IM, and Stein LY. 2014. The Family Nitrosomonadaceae. In: Rosenberg E, DeLong EF, Lory S, Stackebrandt E, and Thompson F, eds. The Prokaryotes: Alphaproteobacteria and Betaproteobacteria. Berlin, Heidelberg: Springer Berlin Heidelberg, 901-918.

Prosser JI, and Nicol GW. 2008. Relative contributions of archaea and bacteria to aerobic ammonia oxidation in the environment. Environmental Microbiology 10:2931-2941. 10.1111/j.14622920.2008.01775.x

Raghoebarsing AA, Pol A, van de Pas-Schoonen KT, Smolders AJP, Ettwig KF, Rijpstra WIC, Schouten S, Damste JSS, Op den Camp HJM, Jetten MSM, and Strous M. 2006. A microbial consortium couples anaerobic methane oxidation to denitrification. Nature 440:918-921. http://www.nature.com/nature/journal/v440/n7086/suppinfo/nature04617 S1.html 
928

929

930

931

932

933

934

935

936

937

938

939

940

941

942

943

944

945

946

947

948

949

950

951

952

953

954

955

956

957

958

959

960

961

962

963

964

965

966

967

968

969

970

971

972

973

974

Richter A, Stoeckl K, Denic M, and Geist J. 2016. Association between the occurrence of the Thick-shelled River Mussel (Unio crassus) and macroinvertebrate, microbial, and diatom communities.

Freshwater Science 35:922-933. 10.1086/687811

Rikmann E, Zekker I, Tomingas M, Tenno T, Loorits L, Vabamae P, Mandel A, Raudkivi M, Daija L, Kroon $\mathrm{K}$, and Tenno T. 2016. Sulfate-reducing anammox for sulfate and nitrogen containing wastewaters. Desalination and Water Treatment 57:3132-3141. 10.1080/19443994.2014.984339

Rios-Del Toro EE, and Cervantes FJ. 2016. Coupling between anammox and autotrophic denitrification for simultaneous removal of ammonium and sulfide by enriched marine sediments. Biodegradation 27:107-118. 10.1007/s10532-016-9759-4

Schilling KE, Wolter CF, and McLellan E. 2015. Agro-hydrologic Landscapes in the Upper Mississippi and Ohio River Basins. Environmental Management 55:646-656. 10.1007/s00267-014-0420-x

Schramm A, De Beer D, Gieseke A, and Amann R. 2000. Microenvironments and distribution of nitrifying bacteria in a membrane-bound biofilm. Environmental Microbiology 2:680-686. 10.1046/j.14622920.2000.00150.x

Schrum HN, Spivack AJ, Kastner M, and D'Hondt S. 2009. Sulfate-reducing ammonium oxidation: A thermodynamically feasible metabolic pathway in subseafloor sediment. Geology 37:939-942. 10.1130/g30238a.1

Schwalb AN, and Pusch MT. 2007. Horizontal and vertical movements of unionid mussels in a lowland river. Journal of the North American Benthological Society 26:261-272. 10.1899/08873593(2007)26[261:havmou]2.0.co;2

Sekiguchi Y, Muramatsu M, Imachi H, Narihiro T, Ohashi A, Harada H, Hanada S, and Kamagata Y. 2008. Thermodesulfovibrio aggregans sp nov and Thermodesulfovibrio thiophilus sp nov., anaerobic, thermophilic, sulfate-reducing bacteria isolated from thermophilic methanogenic sludge, and emended description of the genus Thermodesulfovibrio. International Journal of Systematic and Evolutionary Microbiology 58:2541-2548. 10.1099/ijs.0.2008/000893-0

Shannon JM, Hauser LW, Liu X, Parkin GF, Mattes TE, and Just CL. 2015. Partial nitritation ANAMMOX in submerged attached growth bioreactors with smart aeration at 20 [degree]C. Environmental Science: Processes \& Impacts 17:81-89. 10.1039/C4EM00481G

Shen JP, Xu ZH, and He JZ. 2014. Frontiers in the microbial processes of ammonia oxidation in soils and sediments. Journal of Soils and Sediments 14:1023-1029. 10.1007/s11368-014-0872-x

Shen L-d, Wu H-s, Gao Z-q, Ruan Y-j, Xu X-h, Li J, Ma S-j, and Zheng P-h. 2016. Evidence for anaerobic ammonium oxidation process in freshwater sediments of aquaculture ponds. Environmental Science and Pollution Research 23:1344-1352. 10.1007/s11356-015-5356-Z

Shen LD, Liu S, He ZF, Lian X, Huang Q, He YF, Lou LP, Xu XY, Zheng P, and Hu BL. 2015. Depth-specific distribution and importance of nitrite-dependent anaerobic ammonium and methane-oxidising bacteria in an urban wetland. Soil Biology \& Biochemistry 83:43-51. 10.1016/j.soilbio.2015.01.010

Shen LD, Wu HS, Liu X, and Li J. 2017. Vertical distribution and activity of anaerobic ammonium-oxidising bacteria in a vegetable field. Geoderma 288:56-63. 10.1016/j.geoderma.2016.11.007

Sonthiphand P, Hall MW, and Neufeld JD. 2014. Biogeography of anaerobic ammonia-oxidizing (anammox) bacteria. Frontiers in Microbiology. 10.3389/fmicb.2014.00399

Sonthiphand P, and Neufeld JD. 2013. Evaluating Primers for Profiling Anaerobic Ammonia Oxidizing Bacteria within Freshwater Environments. Plos One 8. 10.1371/journal.pone.0057242

Spang A, Poehlein A, Offre P, Zumbragel S, Haider S, Rychlik N, Nowka B, Schmeisser C, Lebedeva EV, Rattei T, Bohm C, Schmid M, Galushko A, Hatzenpichler R, Weinmaier T, Daniel R, Schleper C, Spieck E, Streit W, and Wagner M. 2012. The genome of the ammonia-oxidizing Candidatus 
975

976

977

978

979

980

981

982

983

984

985

986

987

988

989

990

991

992

993

994

995

996

997

998

999

1000

1001

1002

1003

1004

1005

1006

1007

1008

1009

1010

1011

1012

1013

1014

1015

1016

1017

1018

1019

1020

1021

1022

Nitrososphaera gargensis: insights into metabolic versatility and environmental adaptations. Environmental Microbiology 14:3122-3145. 10.1111/j.1462-2920.2012.02893.x

Strayer DL. 2014. Understanding how nutrient cycles and freshwater mussels (Unionoida) affect one another. Hydrobiologia 735:277-292. 10.1007/s10750-013-1461-5

Strous M, Kuenen JG, Fuerst JA, Wagner M, and Jetten MSM. 2002. The anammox case - A new experimental manifesto for microbiological eco-physiology. Antonie Van Leeuwenhoek International Journal of General and Molecular Microbiology 81:693-702. 10.1023/a:1020590413079

Sun W, Xu MY, Wu WM, Guo J, Xia CY, Sun GP, and Wang AJ. 2014. Molecular diversity and distribution of anammox community in sediments of the Dongjiang River, a drinking water source of Hong Kong. Journal of Applied Microbiology 116:464-476. 10.1111/jam.12367

Tenore KR, and Dunstan WM. 1973. Comparison of feeding and biodeposition of three bivalves at different food levels. Marine Biology 21:190-195. 10.1007/bf00355249

Thamdrup B. 2012. New Pathways and Processes in the Global Nitrogen Cycle. In: Futuyma DJ, ed. Annual Review of Ecology, Evolution, and Systematics, Vol 43, 407-428.

Trabal N, Mazon-Suastegui JM, Vazquez-Juarez R, Asencio-Valle F, Morales-Bojorquez E, and Romero J. 2012. Molecular Analysis of Bacterial Microbiota Associated with Oysters (Crassostrea gigas and Crassostrea corteziensis) in Different Growth Phases at Two Cultivation Sites. Microbial Ecology 64:555-569. 10.1007/s00248-012-0039-5

Trimmer M, and Engstrom P. 2011. DISTRIBUTION, ACTIVITY, AND ECOLOGY OF ANAMMOX BACTERIA IN AQUATIC ENVIRONMENTS. Nitrification:201-235.

van Bodegom P, Stams F, Mollema L, Boeke S, and Leffelaar P. 2001. Methane oxidation and the competition for oxygen in the rice rhizosphere. Applied and Environmental Microbiology 67:3586-3597. 10.1128/aem.67.8.3586-3597.2001

van Kessel M, Speth DR, Albertsen M, Nielsen PH, Op den Camp HJM, Kartal B, Jetten MSM, and Lucker S. 2015. Complete nitrification by a single microorganism. Nature 528:555-+. $10.1038 /$ nature16459

Vaughn CC, and Hakenkamp CC. 2001. The functional role of burrowing bivalves in freshwater ecosystems. Freshwater Biology 46:1431-1446. 10.1046/j.1365-2427.2001.00771.x

Wakelin SA, Colloff MJ, and Kookana RS. 2008. Effect of wastewater treatment plant effluent on microbial function and community structure in the sediment of a freshwater stream with variable seasonal flow. Applied and Environmental Microbiology 74:2659-2668. 10.1128/aem.02348-07

Wang HL, Ji GD, Bai XY, and He CG. 2015. Assessing nitrogen transformation processes in a trickling filter under hydraulic loading rate constraints using nitrogen functional gene abundances. Bioresource Technology 177:217-223. 10.1016/j.biortech.2014.11.094

Wang Q, Garrity GM, Tiedje JM, and Cole JR. 2007. Naive Bayesian classifier for rapid assignment of rRNA sequences into the new bacterial taxonomy. Applied and Environmental Microbiology 73:5261-5267. 10.1128/aem.00062-07

Welte CU, Rasigraf O, Vaksmaa A, Versantvoort W, Arshad A, Op den Camp HJM, Jetten MSM, Lüke C, and Reimann J. 2016. Nitrate- and nitrite-dependent anaerobic oxidation of methane. Environmental Microbiology Reports 8:941-955. 10.1111/1758-2229.12487

Winkler MKH, Ettwig KF, Vannecke TPW, Stultiens K, Bogdan A, Kartal B, and Volcke EIP. 2015. Modelling simultaneous anaerobic methane and ammonium removal in a granular sludge reactor. Water Research 73:323-331. https://doi.org/10.1016/j.watres.2015.01.039

Yang J, Trela J, Zubrowska-Sudol M, and Plaza E. 2015. Intermittent aeration in one-stage partial nitritation/anammox process. Ecological Engineering 75:413-420. http://dx.doi.org/10.1016/j.ecoleng.2014.11.016 
1023

1024

1025

1026

1027

1028

1029

1030

1031

1032

1033

1034

1035

1036

1037

1038

1039

1040

1041

1042

1043

1044

1045

1046

1047

1048

1049

1050

1051

1052

1053

1054

1055

1056
Young NC. 2006. Physical characterization of freshwater mussel habitats in upper mississippi river pool 16. (Order No 3229716) Available from ProQuest Dissertations \& Theses Global (305340701) Retrieved from http://proxylibuiowaedu/login?url=http://searchproquestcom/docview/305340701?accountid=1 4663.

Zeng J, Yang LY, Liang Y, Li JY, Xiao L, Jiang LJ, and Zhao DY. 2008. Spatial distribution of bacterial communities in sediment of a eutrophic lake revealed by denaturing gradient gel electrophoresis and multivariate analysis. Canadian Journal of Microbiology 54:1053-1063. 10.1139/w08-098

Zhalnina KV, Dias R, Leonard MT, Dorr de Quadros P, Camargo FAO, Drew JC, Farmerie WG, Daroub SH, and Triplett EW. 2014. Genome Sequence of Candidatus Nitrososphaera evergladensis from Group I.1b Enriched from Everglades Soil Reveals Novel Genomic Features of the AmmoniaOxidizing Archaea. Plos One 9:e101648. 10.1371/journal.pone.0101648

Zhang JX, Yang YY, Zhao L, Li YZ, Xie SG, and Liu Y. 2015. Distribution of sediment bacterial and archaeal communities in plateau freshwater lakes. Applied Microbiology and Biotechnology 99:32913302. 10.1007/s00253-014-6262-x

Zhang RJ, Cui B, and Huang SB. 2014. Algae Consumption and Nitrate Removal in a Raw Water Transport System by Limnoperna fortunei and its Associated Microorganisms. Water Environment Research 86:2301-2308. 10.2175/106143014x13987223590209

Zheng YL, Hou LJ, Liu M, Yin GY, Gao J, Jiang XF, Lin XB, Li XF, Yu CD, and Wang R. 2016. Community composition and activity of anaerobic ammonium oxidation bacteria in the rhizosphere of saltmarsh grass Spartina alterniflora. Applied Microbiology and Biotechnology 100:8203-8212. 10.1007/s00253-016-7625-2

Zhu B, van Dijk G, Fritz C, Smolders AJP, Pol A, Jetten MSM, and Ettwig KF. 2012. Anaerobic Oxidization of Methane in a Minerotrophic Peatland: Enrichment of Nitrite-Dependent Methane-Oxidizing Bacteria. Applied and Environmental Microbiology 78:8657-8665. 10.1128/AEM.02102-12

Zhu G, Wang S, Wang Y, Wang C, Risgaard-Petersen N, Jetten MSM, and Yin C. 2011. Anaerobic ammonia oxidation in a fertilized paddy soil. The ISME Journal 5:1905-1912. 10.1038/ismej.2011.63

Zhu X, Burger M, Doane TA, and Horwath WR. 2013. Ammonia oxidation pathways and nitrifier denitrification are significant sources of $\mathrm{N} 2 \mathrm{O}$ and NO under low oxygen availability. Proceedings of the National Academy of Sciences 110:6328-6333. 10.1073/pnas.1219993110 
1058 Table 1: Percent relative abundance of N-cycle organisms for mussel and depth treatments.

\begin{tabular}{|c|c|c|c|c|c|}
\hline \multirow{2}{*}{ Taxonomic Classification } & \multirow{2}{*}{$\begin{array}{c}\text { N-Cycle } \\
\text { Classification }\end{array}$} & $\begin{array}{c}3 \mathrm{~cm} \text { with- } \\
\text { mussels }\end{array}$ & $3 \mathrm{~cm}$ no-mussels & 5 cm with-mussels & 5 cm no-mussels \\
\cline { 3 - 6 } & AOA & 0.26 & 0.44 & 0.22 \\
\hline Candidatus Nitrososphaera & nitrate-damo & 0.12 & 0.21 & 0.11 & 0.0035 \\
\hline ANME-2D & nitrite-damo & 0.0039 & 0.02 & 1.11 & 0.08 \\
\hline Nitrospira & NOB/comammox & 1.92 & 1.00 & 0.07 & 0.15 \\
\hline Candidatus Brocadia & anammox & 0.10 & 0.05 & 0.13 & 0.10 \\
\hline
\end{tabular}

1059

1060 


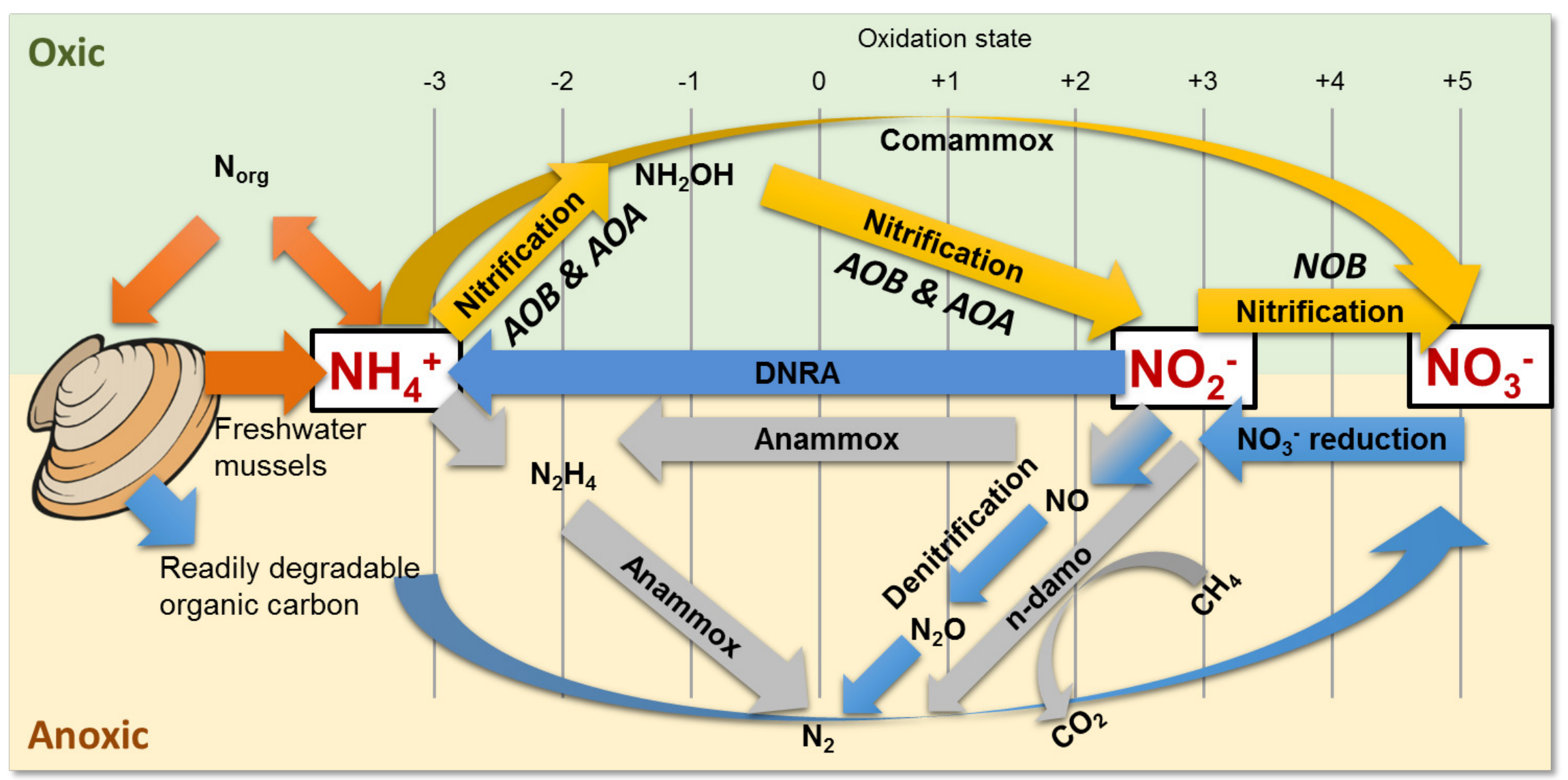

Figure 1: Freshwater mussels deposit feces and pseudofeces containing nitrogen and carbon at the water-sediment interface (i.e. oxicanoxic transition). $\mathrm{NH}_{4}{ }^{+}$resulting from mussel biodeposits may be oxidized via nitrification and comammox in oxic conditions

(yellow arrows), and/or by anammox and n-damo near the oxic-anoxic interface (gray arrows). Oxidized nitrogen species $\left(\mathrm{NO}_{2}{ }^{-}\right.$and $\mathrm{NO}_{3}^{-}$) may be reduced by dissimilatory nitrate reduction to ammonium (DNRA) and denitrification pathways (blue). 


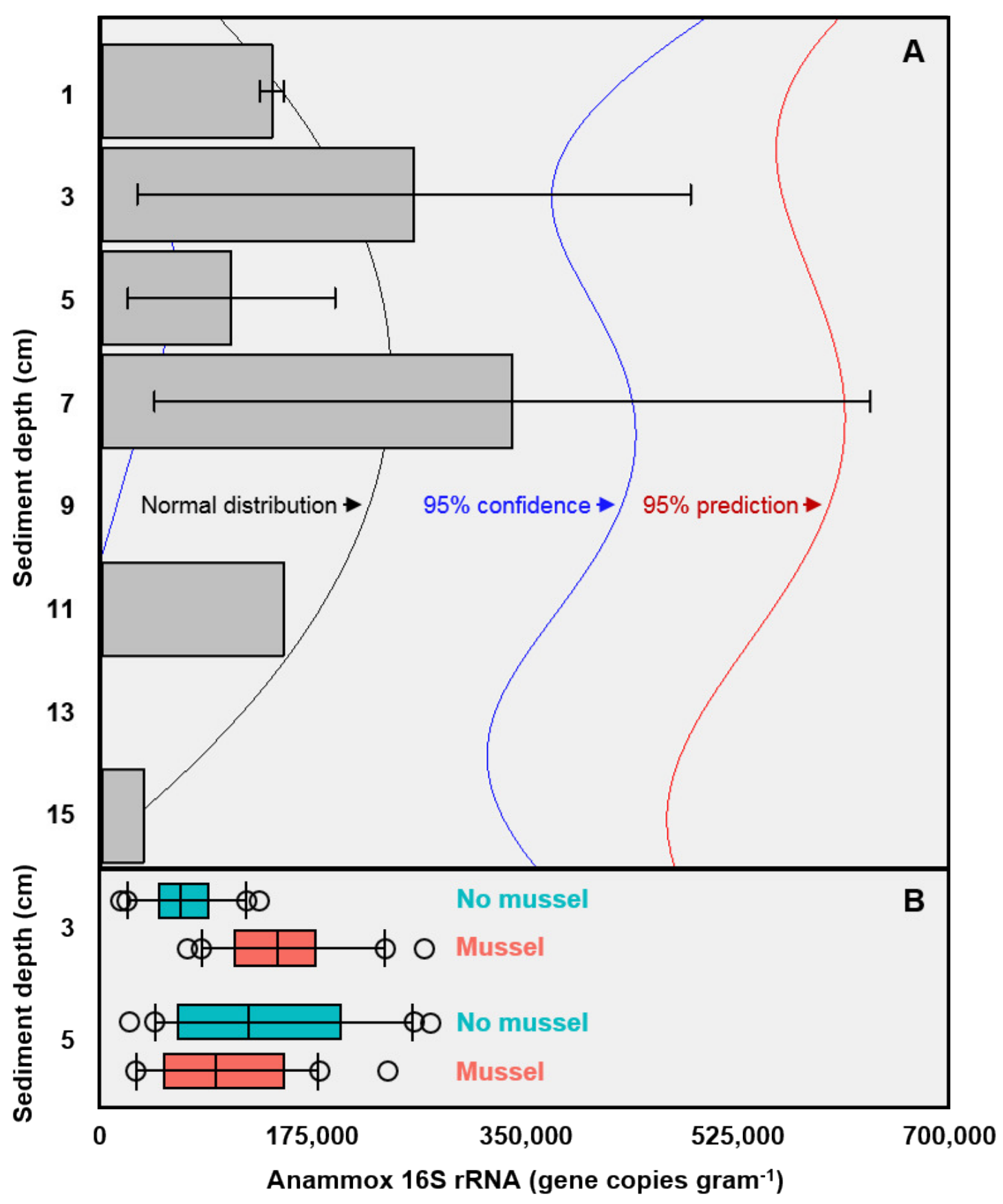

1067 Figure 2: A) The mean anammox 16S rRNA gene copies (per gram of sediment) in the presence 1068 of mussels were normally distributed (Shapiro-Wilk normality test, W-statistic $=0.954, p=0.773$ ) with depth (Batch 1 data). Error bars represent 1 standard deviation from the mean. B) Mussels (salimon-colored data) significantly increased the anammox 16S rRNA gene copies at $3 \mathrm{~cm}$ depth $(\mathrm{p}<0.001$; Batch 2 data). The anammox gene copies were statistically indistinguishable with mussels as compared to the no mussels (turquoise-colored data) sediments at $5 \mathrm{~cm}$ (Batch 2 data). The outer most open circles in Figure 2B represent data outliers, box boundaries represent the $25^{\text {th }}$ and $75^{\text {th }}$ percentile, the line within the box is the median, and error bars indicate $10^{\text {th }}$ and $90^{\text {th }}$ percentiles. 

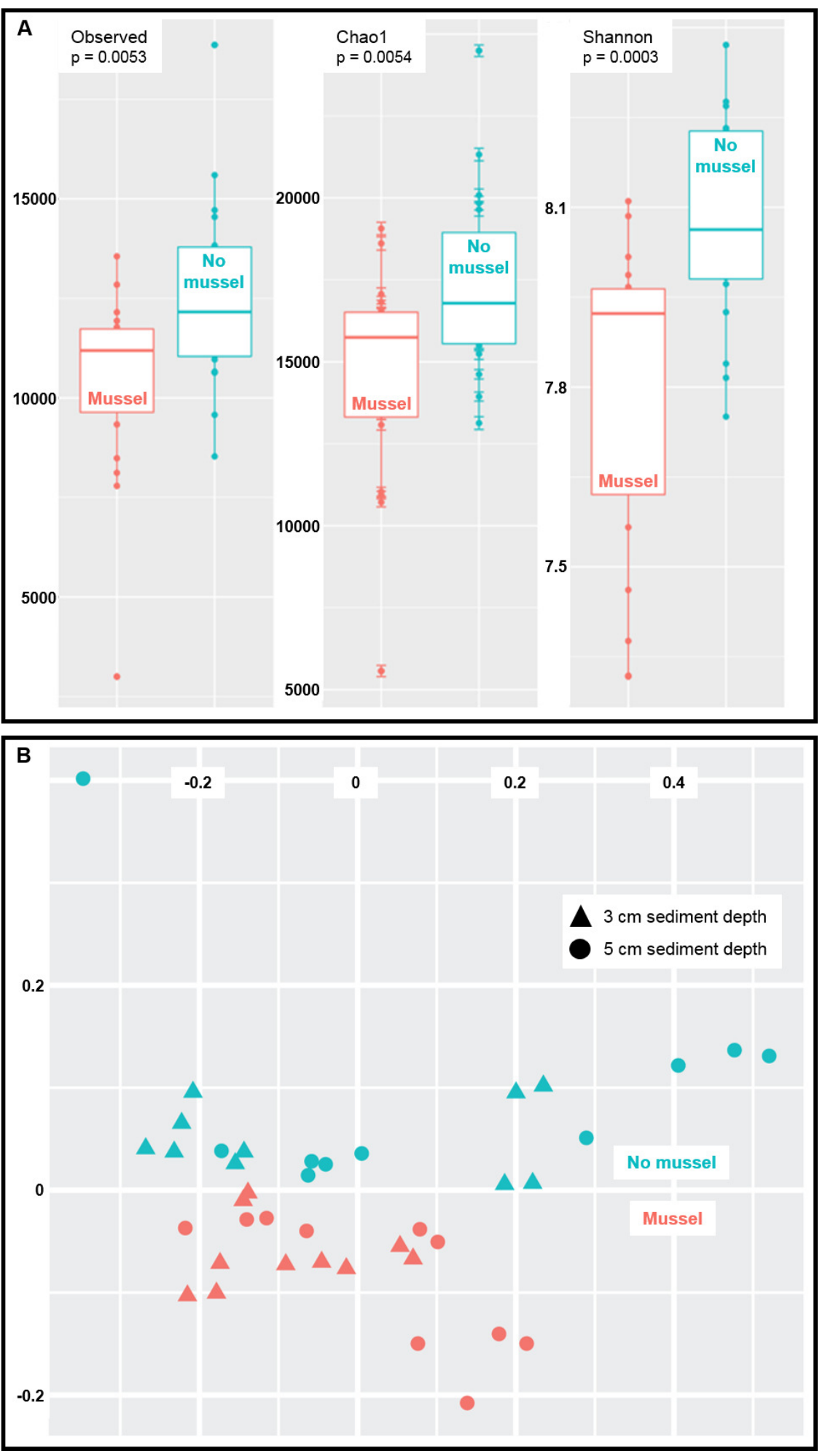

1077 Figure 3: A) Sediments with mussels have lower observed species richness $(\mathrm{p}=0.005)$, Chao1 1078 diversity $(\mathrm{p}=0.005)$, and Shannon $(\mathrm{p}=0.0003)$ diversity than no-mussel sediments. B) NMDS 1079 analysis using bray-curtis distances revealed sample clustering as a function of mussel presence, 1080 but not sediment depth. 


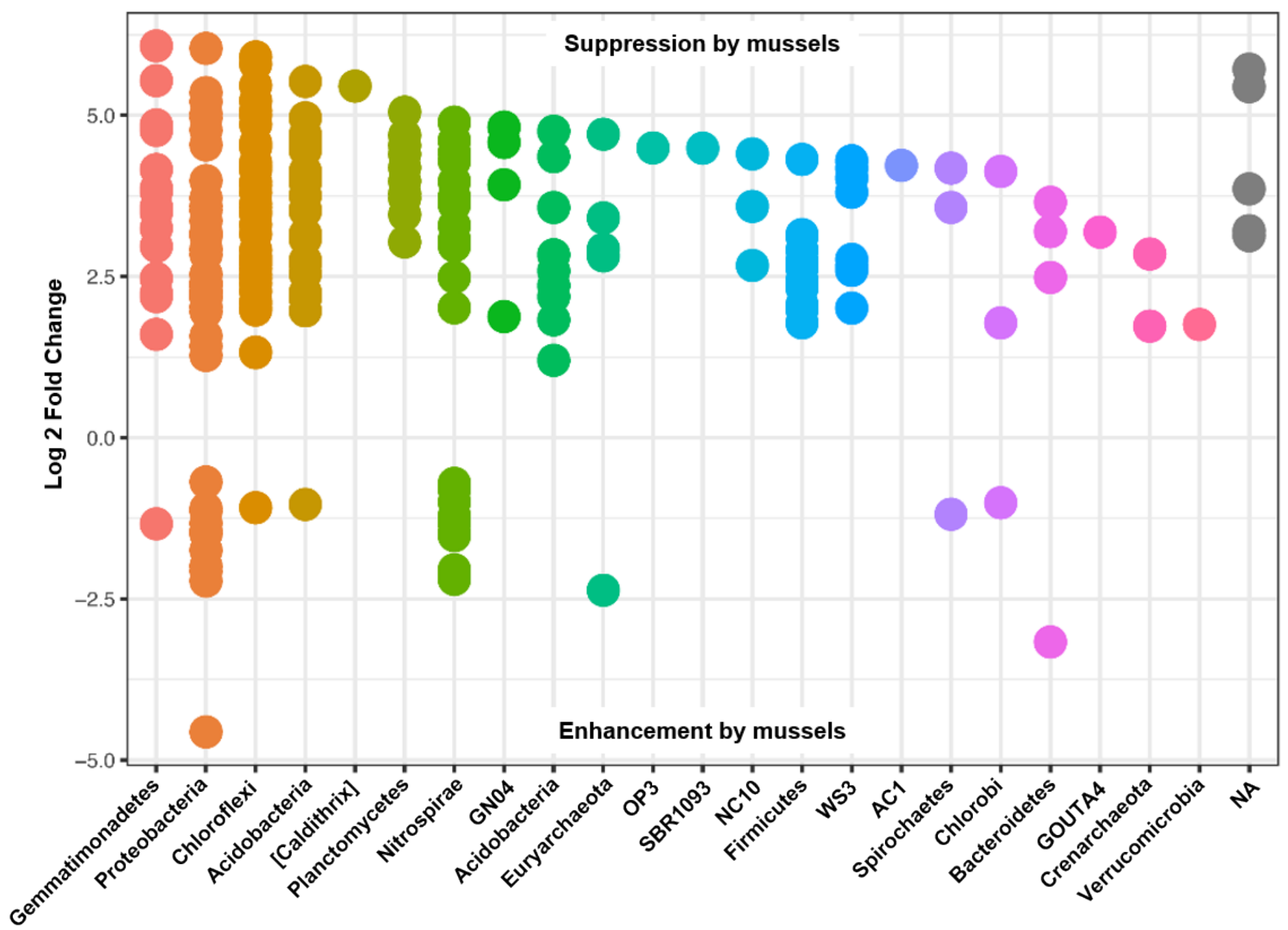

Figure 4: Results from a DESeq2 differential abundance analysis expressed as Log2FC comparison of with-mussels and no-mussels samples. Negative Log2FC represent phyla enhanced in the mussel bed and each point represents an individual OTU. To enhance clarity, only those OTUs with $\mathrm{p}$-adj $<0.0001$ are shown. 


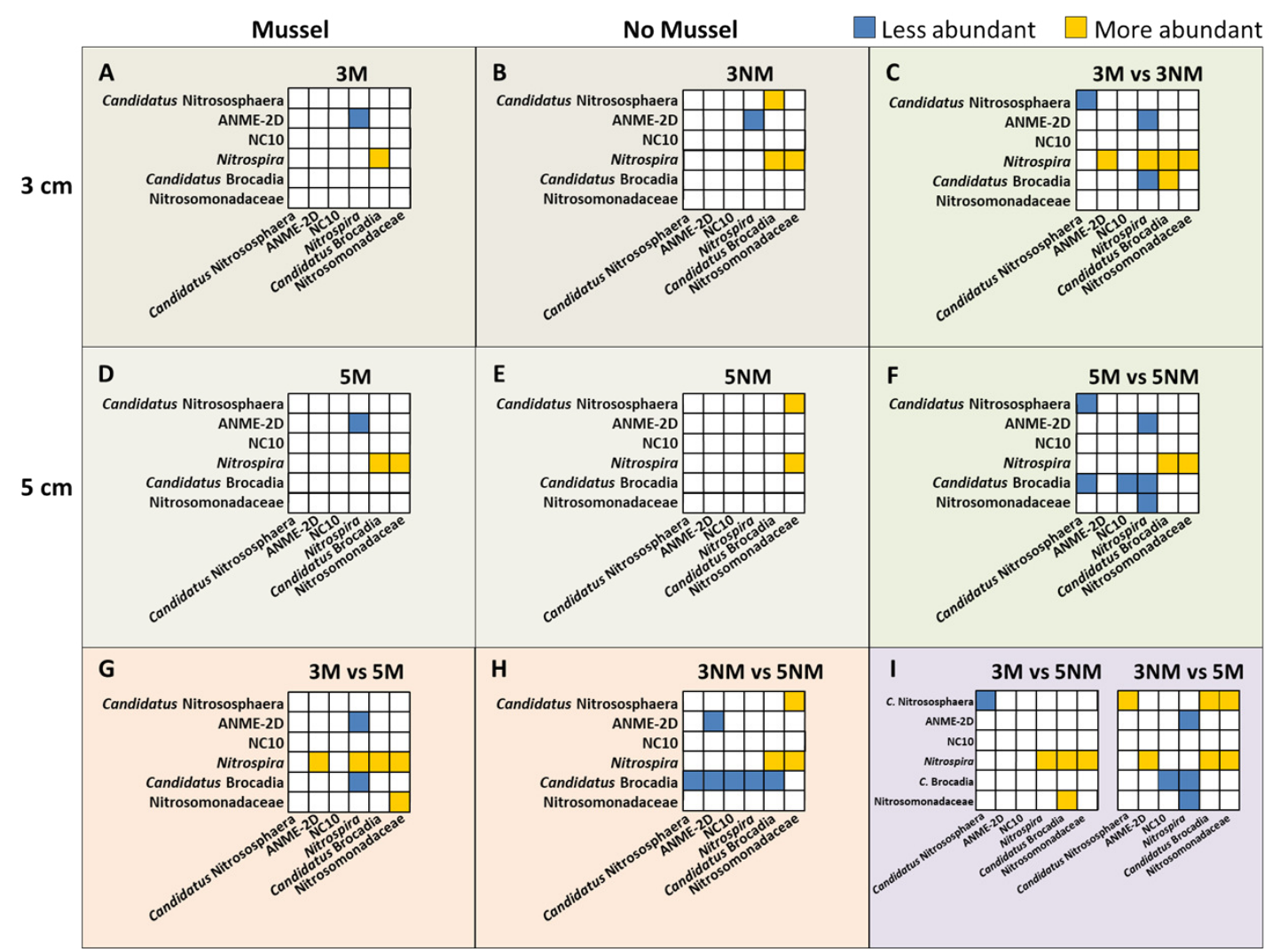

Figure 5: Statistically significant differences in N-cycle phylotype relative abundances (Padj<0.05). All boxes show y-axes compared to the "baseline" $x$-axes, with no boxes representing comparisons not meeting significance. Boxes A-B, D-E: Comparisons within treatment conditions of mussel presence and depth. Box C: Differentially abundant phylotypes between $3 \mathrm{~cm}$ mussel and $3 \mathrm{~cm}$ no mussel treatments. Box F: Relative abundance comparisons between $5 \mathrm{~cm}$ mussel and $5 \mathrm{~cm}$ no mussel treatments. Box G: Differential N-cycle phylotype abundances between $3 \mathrm{~cm}$ mussel and $5 \mathrm{~cm}$ mussel samples. Box H: Comparisons between $3 \mathrm{~cm}$ no mussel and $5 \mathrm{~cm}$ no mussel treatments. Box I: Abundance comparisons of $3 \mathrm{~cm}$ Mussel versus $5 \mathrm{~cm}$ no mussel, and 3 no mussel versus 5 mussel samples. 